\title{
Impact of MYC on Anti-Tumor Immune Responses in Aggressive B Cell Non-Hodgkin Lymphomas: Consequences for Cancer Immunotherapy
}

\author{
A. Vera de Jonge ${ }^{1, *(\mathbb{D}}$, Tuna Mutis ${ }^{1}$, Margaretha G. M. Roemer ${ }^{2}{ }^{(}$, Blanca Scheijen $^{3}(\mathbb{C}$ and \\ Martine E. D. Chamuleau ${ }^{1}$ \\ 1 Department of Hematology, Amsterdam UMC, VU University Medical Center, Cancer Center Amsterdam, \\ 1081HV Amsterdam, The Netherlands; t.mutis@amsterdamumc.nl (T.M.); \\ m.chamuleau@amsterdamumc.nl (M.E.D.C.) \\ 2 Department of Pathology, Amsterdam UMC, VU University Medical Center, Cancer Center Amsterdam, \\ 1081HV Amsterdam, The Netherlands; m.roemer@amsterdamumc.nl \\ 3 Department of Pathology, Radboud UMC, Radboud Institute for Molecular Life Sciences, \\ 6525GA Nijmegen, The Netherlands; blanca.scheijen@radboudumc.nl \\ * Correspondence: a.dejonge1@amsterdamumc.nl
}

Received: 22 September 2020; Accepted: 16 October 2020; Published: 20 October 2020

check for updates

Simple Summary: The human immune system has several mechanisms to attack and eliminate lymphomas. However, the MYC oncogene is thought to facilitate escape from this anti-tumor immune response. Since patients with MYC overexpressing lymphomas face a significant dismal prognosis after treatment with standard immunochemotherapy, understanding the role of MYC in regulating the anti-tumor immune response is highly relevant. In this review, we describe the mechanisms by which MYC attenuates the anti-tumor immune responses in B cell non-Hodgkin lymphomas. We aim to implement this knowledge in the deployment of novel immunotherapeutic approaches. Therefore, we also provide a comprehensive overview of current immunotherapeutic options and we discuss potential future treatment strategies for MYC overexpressing lymphomas.

\begin{abstract}
Patients with MYC overexpressing high grade B cell lymphoma (HGBL) face significant dismal prognosis after treatment with standard immunochemotherapy regimens. Recent preclinical studies indicate that MYC not only contributes to tumorigenesis by its effects on cell proliferation and differentiation, but also plays an important role in promoting escape from anti-tumor immune responses. This is of specific interest, since reversing tumor immune inhibition with immunotherapy has shown promising results in the treatment of both solid tumors and hematological malignancies. In this review, we outline the current understanding of impaired immune responses in B cell lymphoid malignancies with MYC overexpression, with a particular emphasis on diffuse large B cell lymphoma. We also discuss clinical consequences of MYC overexpression in the treatment of HGBL with novel immunotherapeutic agents and potential future treatment strategies.
\end{abstract}

Keywords: MYC; diffuse large B cell lymphoma; high grade B cell lymphoma; tumor immune evasion; MYC inhibition; immunotherapy; T cell therapy

\section{Introduction}

Non-Hodgkin lymphomas (NHL) are the most common hematologic malignancies and can be divided into indolent and aggressive subtypes [1]. Diffuse large B cell lymphoma (DLBCL) is the most common aggressive NHL subtype with an incidence of 695 per 100,000 [2]. The outcome of patients with DLBCL is heterogeneous and dependent on clinical and biological variables. Currently, the only 
prognostic marker that has direct therapeutic implications for first-line therapy is overexpression of the $c-M Y C$ oncogene (hereafter MYC) [3]. MYC overexpression is either due to chromosomal translocation, gene amplification or somatic (hyper)mutations [4]. About $5-15 \%$ of all DLBCLs harbor translocations that affect the MYC gene located on chromosome 8q24.21 as established by fluorescence in situ hybridization (FISH) [5]. Translocation partners involve the enhancer of the immunoglobulin (Ig) heavy chain $[\mathrm{t}(8 ; 14)]$, Ig lambda light chain $[\mathrm{t}(8 ; 22)]$, and Ig kappa light chain genes [t(2;8)] or non-Ig gene regulatory elements [6]. In about $30 \%$ of the MYC translocated DLBCL patients, this is the only translocation (single hit (SH) DLBCL), while in the majority MYC translocations are accompanied by a translocation affecting either the $B C L 2$ or $B C L 6$ gene, referred to as double-hit (DH) high grade $\mathrm{B}$ cell lymphoma (HGBL), or both BCL2 and BCL6 genes, referred to as triple hit (TH) HGBL [1]. Concurrent overexpression of the MYC and BCL2 protein without underlying evidence for gene translocations is known as a "double-expressor" (DE) lymphoma [7]. Recent studies showed that HGBL with specific gene expression signatures (double hit signature (DHITsig) or molecular high-grade (MHG)), were enriched for, but did not exclusively contain, SH, DH or TH HGBLs [8,9]. In this review, we refer to both SH, DH or TH HGBL and DE lymphomas with "MYC overexpression", since this eventually all results in high MYC protein expression.

Over the past decades, the clinical outcome of B cell NHL patients significantly improved with the introduction of immunotherapy by targeting cell surface molecules, such as CD20, with monoclonal antibodies [10]. However, progression free survival and overall survival are poor in patients with MYC translocations after treatment with standard immunochemotherapy for DLBCL (rituximab, cyclophosphamide, doxorubicin, vincristine and prednisone (R-CHOP)) [11-16]. Therefore, patients with DH and TH HGBL are often treated with dose-intensification regimens, such as dose-adjusted etoposide, prednisone, vincristine, cyclophosphamide, doxorubicin and rituximab (DA-EPOCH-R) [17]. Patients with SH and DE lymphomas have a prognosis in between DLBCL patients without MYC overexpression and patients with DH or TH HGBL $[16,18]$. Treatment strategies are usually not adapted for SH and DE lymphoma patients.

In recent years, numerous novel immunotherapeutic strategies have been tested in patients with B cell NHL. This includes immune checkpoint inhibitors, bispecific antibodies and CAR-T cell therapies [19]. To deploy these novel immunotherapeutic strategies in MYC overexpressing lymphoid malignancies, it will be important to understand the effects of MYC overexpression on anti-tumor immune responses. In this review, we highlight current understanding of impaired immune responses in MYC overexpressing lymphoid malignancies with particular emphasis on DLBCL. Preclinical data are illustrated by Burkitt lymphoma (BL; a rare subtype of NHL with a specific morphology and characterized by MYC translocation in $95-99 \%$ of the cases) models [20]. Furthermore, we provide a comprehensive overview of advanced developments in immunotherapeutic strategies for MYC overexpressing lymphoid malignancies.

\section{The Role of MYC in Normal B Cell Development}

MYC is a basic-helix-loop-helix leucine-zipper (bHLH-LZip) nuclear protein that forms a heterodimer with MYC associated factor X (MAX). By binding to a specific DNA sequence, the CACGTG E-box [21], the MYC/MAX heterodimer regulates transcription of 10-15\% genes, that are involved in essential biological processes, such as cell growth, proliferation, differentiation, metabolism, stemness, apoptosis and protein translation [22-25]. As such, MYC regulates the development and maturation of lymphocytes [24,26-29].

Normal B cells develop from a hematopoietic stem cell via lymphoid progenitor cells into an early pro- $B$ cell, pro- $B$ cell, pre- $B$ cell and, finally, an immature $B$ cell. In the transition from the pro- $\mathrm{B}$ cell to pre- $\mathrm{B}$ cell stage, the pre- $\mathrm{B}$ cell receptor $(\mathrm{BCR})$ is expressed, a process that is associated with MYC upregulation [30-32]. MYC promotes B cell proliferation and differentiation by activating several B cell determining genes, such as Cd19 [33-37]. Immature B cells expressing a complete, functional, non-autoreactive BCR downregulate MYC expression, enter the peripheral circulation 
and then accumulate in lymph nodes where further maturation takes place under differential MYC expression [38,39]. MYC is re-expressed after (antigen) activation of the BCR, promoting proliferation and inhibiting differentiation of mature B cells $[39,40]$. After positive selection, MYC expression is downregulated, allowing B cells to differentiate into memory B cells or plasmablasts and to exit the germinal center $[39,41]$. In plasmablasts, MYC expression is suppressed, allowing terminal B cell differentiation into plasma cells [42].

\section{The Role of MYC Overexpression on the Immune System in Lymphoid Malignancies}

\subsection{Impact of MYC Overexpression for Adaptive Immunity}

Tumors possess the ability to evade immune detection and cytotoxic $\mathrm{T}$ cell responses by downregulating antigen presenting and costimulatory molecules and by inducing $\mathrm{T}$ cell tolerance. Research over the past decades has clearly demonstrated the important impact of MYC overexpression on the antigen-specific cross-talk between tumor cells and T cells. The negative influence of MYC on the adaptive immune system occurs at several levels as outlined below. A schematic summary of the effects of MYC overexpression on adaptive and innate anti-tumor immune responses is shown in Figure 1, and a detailed description follows in the text below.

\subsubsection{The Effect of MYC Overexpression on Antigen Presentation}

Evasion of immune surveillance in lymphomas overexpressing MYC was first described in 1985, when Epstein-Barr virus (EBV) positive B cell NHL cell lines harboring an MYC translocation were found insensitive to cytotoxic T cell responses, irrespective of antigen expression [43]. Subsequent studies revealed that MYC overexpressing B cell NHL cell lines downregulates expression of HLA class I molecules, leading to impaired T cell recognition $[44,45]$. This phenomenon has also been widely observed in solid tumors [46-50].

The first clear evidence that MYC also negatively influences HLA class II restricted T cells was provided in 2015 [51]. Inducible overexpression of MYC in a preclinical BL model diminished peptide presentation via HLA class II through decreased expression of class II editor HLA-DM. Conversely, inhibition of MYC elevated HLA-DM and partially restored antigen presentation to CD4+ T cells [51]. These findings were recently confirmed in large gene expression profiling studies of HGBL [8,9].

3.1.2. Consequences of MYC Overexpression on the Expression of Adhesion and Costimulatory Molecules

Intracellular adhesion molecules (ICAMs) and vascular cell adhesion molecule-1 (VCAM-1) are highly important for $\mathrm{T}$ cell recruitment and activation. ICAM-1 promotes $\mathrm{T}$ cell activation and migration upon binding with its receptor lymphocyte function-associated antigen-1 (LFA-1) [52]. In MYC-transfected B-LCL, MYC downregulates surface expression of adhesion molecules LFA-1 [53], CD54 (ICAM-1) and CD58 (LFA-3) [54]. A series of BL biopsies also had a uniformly low LFA-1 expression pattern [53]. NF- $\mathrm{BB}$ target genes, including VCAM-1, are downregulated by MYC overexpression in a B-LCL cell line [55]. MYC overexpression is also inversely correlated with tumor necrosis factor (TNF) super family members lymphotoxin- $\alpha$ (TNFSF1), lymphotoxin- $\beta$ and TNF- $\alpha$, that play a role in $\mathrm{T}$ cell recognition, cell-to-cell communication and adhesion in B cell lymphoma cell lines [56].

The regulation of immune responses is a well-balanced counter play between co-stimulatory and co-inhibitory signals. Costimulatory molecules provide important secondary signals upon ligation to augment $\mathrm{T}$ cell responses. One of the earliest reports on the influence of $M Y C$ on the expression levels of $\mathrm{T}$ cell costimulatory molecules was provided by conditional cell lines, where switching MYC off resulted in CD40 downregulation [57]. CD40, a TNF receptor on B cells, is a costimulatory molecule that binds to CD40L (CD154) on T cells derived from the TNF superfamily [58]. Furthermore, MYC repressed CD80 in both an EBV transformed cell line and a transgenic B cell lymphoma mouse 
model [55,57]. The immunoglobulin superfamily member CD80 binds to co-costimulatory molecules from the CD28/B7 family on T cells [59]. However, in a cohort of 211 de novo DLBCL patients MYC protein overexpression did not correlate with CD40 gene expression, but an association was shown with decreased levels of the co-stimulatory immune checkpoint OX40 (TNFRSF4) gene, decreased T cell receptor signaling molecules and regulatory T cell gene FOXP3 [60].

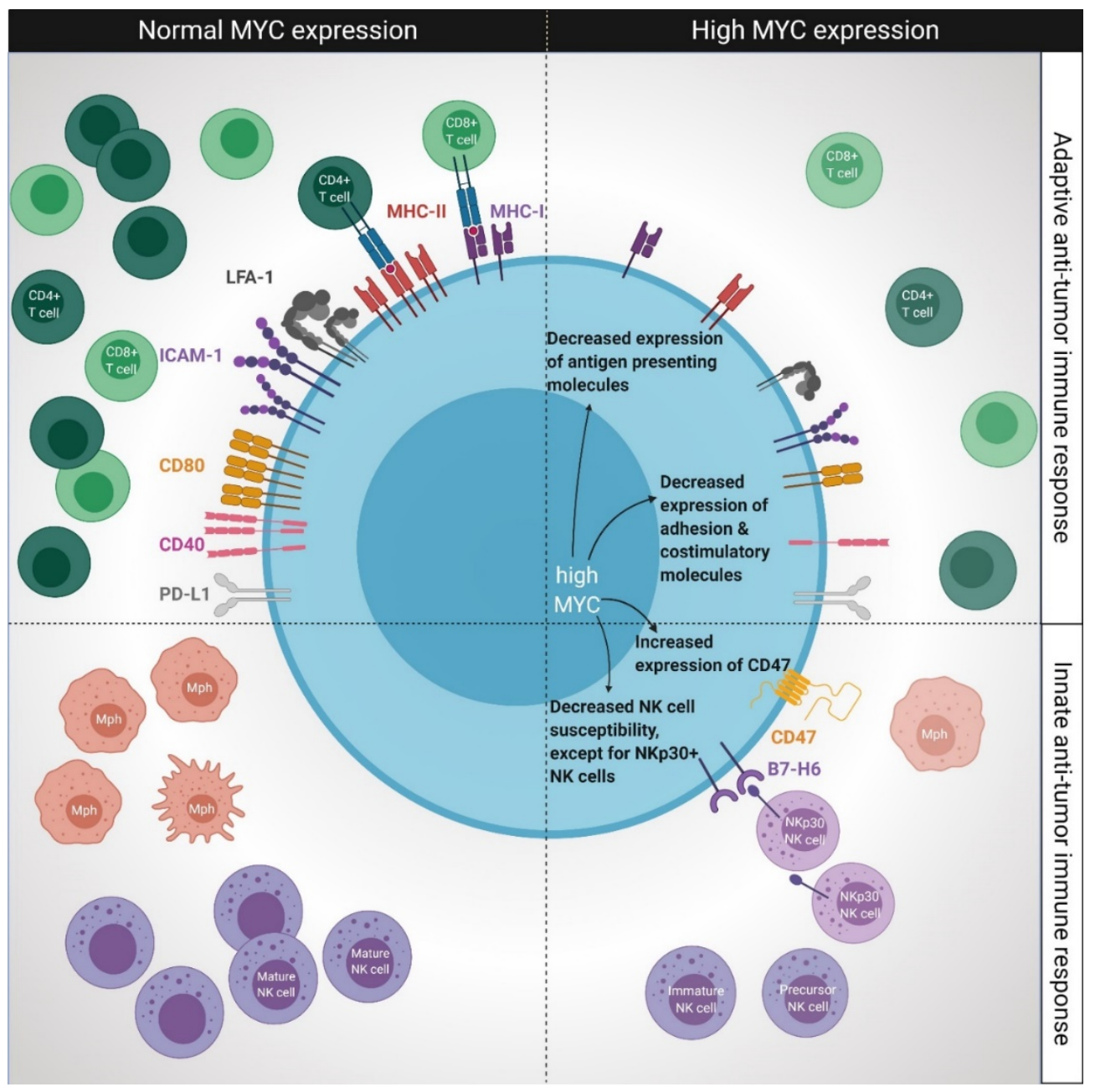

Figure 1. MYC overexpression is associated with reduced T cell-mediated anti-tumor immune responses and impaired innate anti-tumor immune responses by macrophages and NK cells, but not NK cells with the NKp30 receptor. Top left: simplified summary of adaptive immune responses towards malignant cells with normal MYC expression. Top right: MYC overexpression decreases expression of MHC class I and class II molecules, adhesion and costimulatory molecules. MYC overexpression is associated with reduced cytotoxic T cell responses. Different outcomes on the correlation between MYC overexpression and expression of immune checkpoint programmed death-ligand 1 (PD-L1) have been described. Bottom left: simplified summary of innate immune responses towards malignant cells with normal MYC expression. Bottom right: MYC overexpression reduces NK cell amounts, but not cytotoxicity induced via NKp30 NK cells. MYC overexpression induces expression of immune checkpoint CD47, preventing macrophage (Mph)-induced phagocytosis.

\subsubsection{The Role of MYC Overexpression on PD-L1-Mediated T Cell Tolerance}

Programmed death-ligand 1 (PD-L1), also known as B7-H1 or CD274, is a member of the B7 receptor family and the primary ligand for PD-1, one of the most important co-inhibitory molecules on $\mathrm{T}$ cells to regulate excessive $\mathrm{T}$ cell responses [61]. In DLBCL, high PD-L1 expression in tumor 
cells correlates with the non-germinal center B cell (non-GCB) subtype [62-68], inferior treatment outcome $[63,66]$ and decreased progression free survival [66] and overall survival $[62,63,65,68]$.

In various solid tumors, MYC overexpression is correlated with PD-L1 surface expression [69-74] and PD-L1 mRNA expression [69,71-73]. However, the exact relationship between MYC and regulation of PD-L1 expression in lymphoid malignancies is remains unclear. For instance, one study showed a positive correlation between MYC protein and PD-L1 mRNA and protein levels in a cohort of 108 de novo DLBCL patients [67]. In agreement with this, a recent murine study demonstrated that $M y c$ could directly bind to the promotor of $P d-l 1$ and that switching off $M y c$ expression downregulated $P d-l 1$ [75]. This was also found in human DLBCL cell lines treated with MYC inhibitor 10058-F4 or siRNA against $M Y C$ [67].

However, not all studies could confirm a direct relation between MYC and PD-L1. Namely, while a murine study observed PD-L1 downregulation after treatment of Myc endogenous mice with bromodomain inhibitor JQ1, no PD-L1 downregulation was observed after Myc shRNA knockdown [76]. This suggested that decreased PD-L1 expression levels were merely due to other effects of JQ1, rather than Myc downregulation [76]. Another study showed that MYC inactivation could increase PD-L1 mRNA levels [77] and it was proposed that not MYC, but STAT1, directly binds to the regulatory region of PD-L1. Since MYC and STAT1 can regulate their mutual expressions $[78,79]$, it seemed possible that MYC inactivation increased STAT1, leading to increased PD-L1 expression [77]. Furthermore, two other cohorts of de novo and relapsed DLBCL patients reported a negative correlation between MYC and PD-L1 $[63,64]$. Finally, some other studies were not able to detect any correlation between MYC and PD-L1 at all in either DLBCL cell lines [80], nor in DLBCL patients [60,66,68,81]. Notably, EBV infection causes B cells to escape from immune surveillance [82,83] partly by PD-L1 overexpression [84,85], adding further complexity to the relationship between MYC and PD-L1 in EBV-associated DLBCL and BL.

To conclude, these studies employing different technical approaches, showed conflicting outcomes on the exact correlation between MYC and PD-L1 and demonstrate a complex interplay of different factors regulating PD-L1 expression in lymphoid malignancies.

\subsection{Impact of MYC Overexpression for Innate Immunity}

According to the "missing-self" hypothesis, NK cells target infectious and malignant cells mainly upon downregulation of HLA class I on the target cell [86]. As described in the previous section, MYC downregulates HLA class I expression [8,43-45], which would be beneficial for NK cell activity. However, it was recently suggested that downregulation of HLA class I in vivo resulted in NK cell tolerance and that the missing-self hypothesis may not apply to all cells downregulating MHC [87]. Two studies further investigated consequences of MYC overexpression on NK cell-mediated cytotoxicity. Investigating the systemic effects of $M y c$ in murine $\mathrm{T}$ cell lymphomas a recent study showed that Myc expression was associated with lower NKp46 + NK cells in circulation, lower NK cell maturation and more disease progression than control mice [88]. In contrast, another study reported that MYC mRNA levels in B cell lymphomas and solid tumors are positively correlated with B7-H6 expression on the tumor cell, a ligand for the NK cell receptor NKp30. Upon MYC inhibition in BL cell lines, NK cell-mediated degranulation via NKp30 was impaired [89].

In addition to its different effects on NK cells, MYC was found to impair innate immunity by its effects on tumor-associated macrophages (TAMs). In a mouse model of T-ALL overexpressing Myc and in DLBCL cell lines, Myc was associated with high CD47 expression on tumor cells, suppressing recruitment of macrophages and tumor phagocytosis [75,80]. Moreover, inactivation of Myc increased activation of innate immune cells and recruitment of macrophages to the tumor microenvironment [90].

\subsection{Impact of MYC Overexpression on Apoptosis of Tumor Cells}

Cytotoxic activity of $\mathrm{T}$ cells and NK cells is mainly established by induction of apoptosis (programmed cell death) in tumor cells [91]. During normal B cell development, MYC tightly regulates 
apoptosis of the developing B cells [92]. Elevated MYC levels can induce apoptosis, especially in cells that lack adequate levels of cytokines, growth factors or nutrients $[93,94]$. Overexpression of MYC induces apoptosis through activation of the ARF/MDM2/p53 pathway and altering the balance of pro- and anti-apoptotic BCL2 family members [95]. During oncogenic transformation pro-apoptotic functions of MYC are counterbalanced by the acquisition of cooperating gene alterations, such as TP53 mutations and BCL2 overexpression [96,97]. Recently, it has been discovered that the MYC-related transcriptional repressor MNT reduces the level of pro-apoptotic BIM, thereby inhibiting pro-apoptotic functions of MYC [98]. Loss of BIM contributes to lymphomagenesis in a transgenic Myc mouse model [99]. Thus, during transformation the feedback loops involving proteins such as BLIMP1 and BCL6 that under normal circumstances would control MYC's functions are abrogated [100]. The shift towards pro-survival signaling in MYC-transformed lymphoma cells can, therefore, contribute to immunochemotherapy resistance, including reduced sensitivity for $\mathrm{T}$ cell and NK cell-mediated apoptosis.

\subsection{MYC-Dependent Regulation of Metabolism and Interplay with the Immune Microenvironment}

The effects of $M Y C$ on metabolism regulation and its effect on tumor immune microenvironment regulation are summarized in Figure 2.

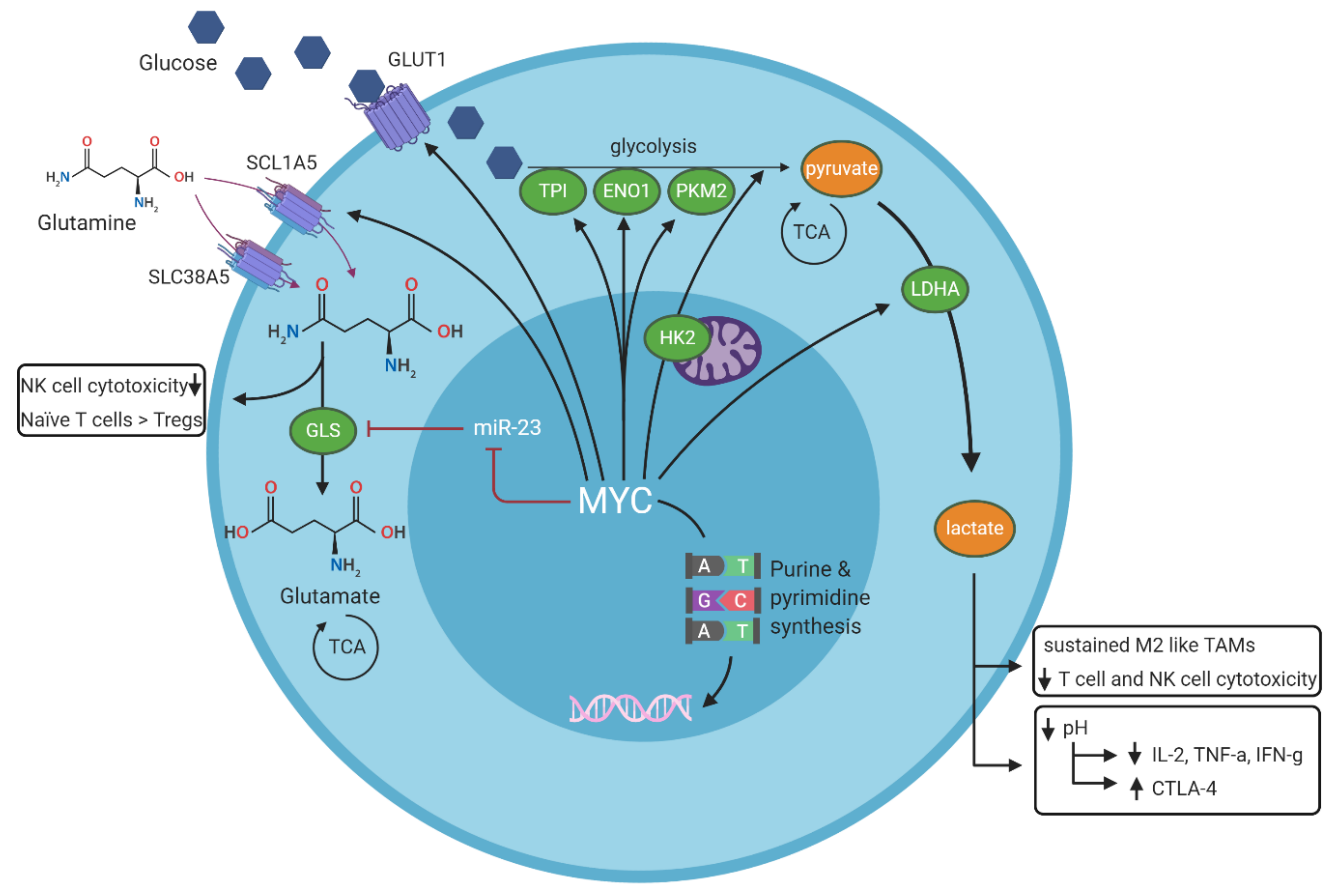

Figure 2. Summary of MYC-dependent regulation of cell metabolism and its effects on the tumor immune environment. MYC stimulates aerobic glycolysis (the conversion of glucose into pyruvate) via glycolytic enzymes TPI, ENO1, PKM2 and HK, and MYC stimulates anaerobic glycolysis (the conversion of glucose into lactate) via LDHA. MYC stimulates glutaminolysis (the conversion of glutamine into glutamate) by inhibiting microRNA-23. Waste products of all three pathways contribute to decreased effector cell cytotoxicity in the tumor immune environment. Green ovals represent enzymes, dark red lines represent inhibitory signals and black arrows represent stimulatory signals. TPI $=$ triose-phosphate isomerase, $\mathrm{ENO} 1$ = enolase 1, PKM2 = M2 isoform of pyruvate kinase, TCA = tricarboxylic acid (TCA) cycle, LDHA = lactate dehydrogenase A, TAMs = tumor associated macrophages, GLS = glutaminase, HK2 = hexokinase 2. GLUT1 = glycose transporter 1, SCL1A5 = solute carrier family 1 member 5 (or alanine serine cysteine transporter 2 , ASCT2), SLC38A5 = solute carrier family 38 member 5 (or sodium-coupled neutral amino acid transporter 5, SNAT5). 
Increased expression of MYC promotes proliferation and growth of cells by inducing metabolic reprogramming and altering intermediary metabolism to match the enhanced demand for anabolic metabolites. Oncogenic levels of MYC promote high consumption of glucose as observed in most cancers, including BL [101-103], which correlates with the ability of MYC to regulate the expression of many genes involved in glycolysis, such as the glucose transporter SLC2A1/GLUT1, the glycolytic enzymes hexokinase 2 (HK2), triose-phosphate isomerase (TPI), enolase 1 (ENO1) and lactate dehydrogenase A (LDHA) [104-106]. MYC overexpression results in enhanced LDHA levels, which utilizes pyruvate as a substrate and converts it into lactate, thereby resulting in extracellular acidification $[107,108]$. Aerobic glycolysis is also driven by MYC-induced differential splicing and increased expression of the M2 isoform of pyruvate kinase (PKM2) [109].

The concept of "glutamine addiction", a phenomenon also described for MYC overexpressing lymphomas [101,110], indicates the increased demand for glutamine as a source of carbon and nitrogen in cancer cells. By regulating expression of glutamine transporter genes SCL1A5 (or ASCT2) and SLC38A5 (or SNAT5), MYC facilitates transport of glutamine into the cell [111]. An important component of the glutaminolytic pathway is the enzyme glutaminase (GLS), which catalyzes the conversion of glutamine into glutamate. MYC upregulates the expression of GLS both directly and indirectly, through MYC-mediated repression of microRNA (miR)-23 transcription, which in turn suppresses GLS translation [110,111]. To couple metabolic reprogramming with nucleotide synthesis, MYC regulates many genes involved in purine and pyrimidine synthesis [112-114].

Overall, the high energy demand of cancer cells together with a poor vascular flow and defective lymphatic drainage will result in a shortage of key metabolites and the abundance of waste products in the tumor microenvironment [115]. In the context of lymphomas with MYC overexpression, there is a tight competition for vital nutrients with the neighboring immune cells, and a negative impact of specific by-products generated by the MYC-expressing lymphoma cells. Lactate, the waste product of glycolysis and glutaminolysis, is considered an immunosuppressive metabolite that impairs immune surveillance of cytotoxic T cells and NK cells [116,117], recruits immunosuppressive regulatory T cells [118] and sustains the M2-like phenotype of TAMs $[119,120]$. Furthermore, glucose deprivation in the tumor microenvironment itself impairs T cell metabolic fitness by reducing T cell survival, IFN- $\gamma$ production and upregulating PD-1 expression, leading to decreased anti-tumor immune responses [121]. Acidic conditions reduce the secretion of certain cytokines (IL-2, TNF- $\alpha$, IFN- $\gamma$ ) by T cells, and upregulate CTLA-4 expression [122]. Other negative effects that have been reported in tumors as a consequence of competition with metabolites involve the differentiation of naïve $\mathrm{T}$ cells into immunosuppressive regulatory T cells (Tregs) and impaired NK cell function due to low glutamine levels [123-125].

\section{Direct and Indirect MYC Modulating Drugs and Consequences for Immune Effector Cells}

Despite wide efforts of studying MYC and its functions over the past decades, MYC has been considered an "undruggable" target for a long time. Moreover, narrow therapeutic windows and on- and off-target toxicities due to the complex interactome of MYC have been a major limitation for clinical testing of MYC inhibitors. Various attempts to target MYC in preclinical models and clinical studies are discussed in detail elsewhere [126-129]. Here, we will summarize some of the currently available drugs that directly and indirectly modulate MYC with specific emphasis on their possible impact on immune responses.

\subsection{Bromodomain Inhibitors}

Bromodomain inhibitors inhibit MYC transcription by competitively binding to bromodomain containing proteins (BRDT, BRD2, BRD3, BRD4), thereby preventing histone acetylation. JQ1 is a small molecule that competitively binds to BRD4 [130]. JQ1 is widely used to study the effects of MYC downregulation in lymphoid malignancies $[75,76,80,131]$. Bromodomain inhibitor analog, CPI-0610, has been well tolerated in patients with DLBCL in a phase I study [132]. However, due to its effects on BRD4 target genes, JQ1 inhibits MYC non-specifically [130]. For example, bromodomain inhibitors 
impair T cell survival, T cell activation and repress IFN- $\gamma$ secretion [133-135]. On the other hand, T cells treated with JQ1 show enhanced anti-tumor immune responses in vivo [136]. The accompanying high amount of on- and off-target toxicities form a major limitation for clinical implementation of bromodomain inhibitors.

\subsection{PI3K Inhibitors}

Translation of MYC mRNA is partly regulated by mammalian target of rapamycin (mTOR), which is activated by AKT after its phosphorylation by phosphoinositide 3-kinase (PI3K) [137]. Kinases of the intracellular PI3K/AKT/mTOR signaling pathway regulate translation and posttranslational phosphorylation of MYC. The PI3K/AKT/mTOR pathway contributes to metabolic reprogramming at least partly via MYC [137]. Kinase inhibitors targeting the PI3K/AKT/mTOR pathway do not only serve as indirect MYC inhibitors, but also directly target cancer metabolism. Furthermore, the PI3K/AKT/mTOR signaling pathway is as an essential pathway in regulating cell metabolism, cell growth and cell differentiation, evenly well required in innate immune cells and effector and memory T cells [138,139]. Specifically, PI3K regulates Th1, Th2 and Th17 cell differentiation [140]. Furthermore, cytotoxic T cell trafficking and activation of cytotoxic T and NK cell effector functions are dependent on PI3K/AKT signaling [140,141], suggesting that these inhibitors may also play a role in modulating immune responses.

TGR-1202 selectively inhibits PI3K $\delta$ in lymphoma, leading to decreased MYC protein levels and induced lymphoma cell death [142]. Idelalisib is the first FDA approved PI3K inhibitor and is now being tested in patients with DLBCL (NCT03576443). Fimepinostat (CUDC-907) is a combined HDAC and PI3K inhibitor that inhibits transcription and consequently downregulates MYC mRNA and protein levels [143]. Results of a phase I study show a tolerable safety profile with endurable anti-tumor responses in patients with MYC overexpressing DLBCL [144].

\subsection{MYC/MAX Dimerization Inhibitors}

Although inhibition of $M Y C$ at transcriptional and translational levels is effective, it is accompanied with multiple off-target effects and MYC protein could still retain a functional level that is regulated post-translationally by various microRNAs [145]. Therapeutic agents inhibiting MYC/MAX dimerization and drugs targeting MYC protein stability may represent more specific and effective therapies for MYC overexpressing lymphoid malignancies.

Preventing MYC/MAX dimerization can either be established by disruption of the MYC/MAX dimer or by inducing and stabilizing MAX/MAX homodimers. The earliest reported protein to prevent MYC/MAX dimerization is Omomyc, a MYC protein derivative from the bHLH-LZip domain with a four amino acid mutation that alters dimerization specificity of MYC [146]. The pharmacological and clinical application of Omomyc is currently being investigated $[147,148]$. Low molecular weight compound 10058-F4 is a common agent used to inhibit MYC/MAX heterodimer formation, inhibiting MYC's biological and oncogenic functions [149,150]. Recently, a small molecule (KI-MS2-008) has been developed that stabilizes the MAX homodimer and prevents dimerization with MYC, resulting in reduced in vivo tumor volume [151]. Although MAX is currently the only known obligate dimerization partner of MYC and disrupting MYC/MAX dimerization significantly reduces MYC activity, MYC still retains some functional MAX-independent activity [152].

Recently developed small molecules MYCi 361 and MYCi 975 destabilize the MYC protein and consequently inhibit tumor growth [153]. A narrow therapeutic window and splenic and hepatic toxicities were reported in preclinical studies for MYCi 361, but MYCi 975 was better tolerable. Both MYC inhibitors displayed additional beneficial effects on enhanced immune cell infiltration in vivo [153]. Combined with anti-PD1 immunotherapy, these MYC inhibitors showed synergistic effects on tumor volume in an in vivo model of prostate cancer [153]. 


\subsection{Immunomodulatory Drugs}

Immunomodulatory drugs (IMiDs) feature, besides anti-proliferative effects, wide immunomodulatory properties, such as co-stimulation of T cells, enhancement of NK cell activity and increased IL-2 and IFN- $\gamma$ secretion $[154,155]$. Lenalidomide, a second generation orally available IMiD, downregulates MYC via interferon regulatory factor 4 (IRF-4). IRF-4 is downregulated after binding of IMiDs to Cereblon and consequent ubiquination and degradation of its substrate proteins [156,157]. Addition of lenalidomide to standard chemotherapy in patients with MYC overexpressing DLBCL is safe and results in comparable responses to outcomes of intensified chemotherapy regimens [158]. Similar studies investigating lenalidomide in combination with standard chemotherapy in patients with DLBCL are ongoing (DA-EPOCH; NCT02213913, or R-CHOP; NCT04164368).

\section{Immunotherapies in DLBCL, with Special Emphasis on Patients with MYC Overexpression}

In this section, we review current clinical outcomes of DLBCL patients treated with various immunotherapeutic strategies. Only a limited number of studies were specifically designed for lymphomas with MYC overexpression. Most studies reported outcome of patients with MYC overexpression and MYC normal expression as subgroups. Figure 3 summarizes current immunotherapeutic treatment strategies and their possible mechanism of action in MYC overexpressing DLBCL.

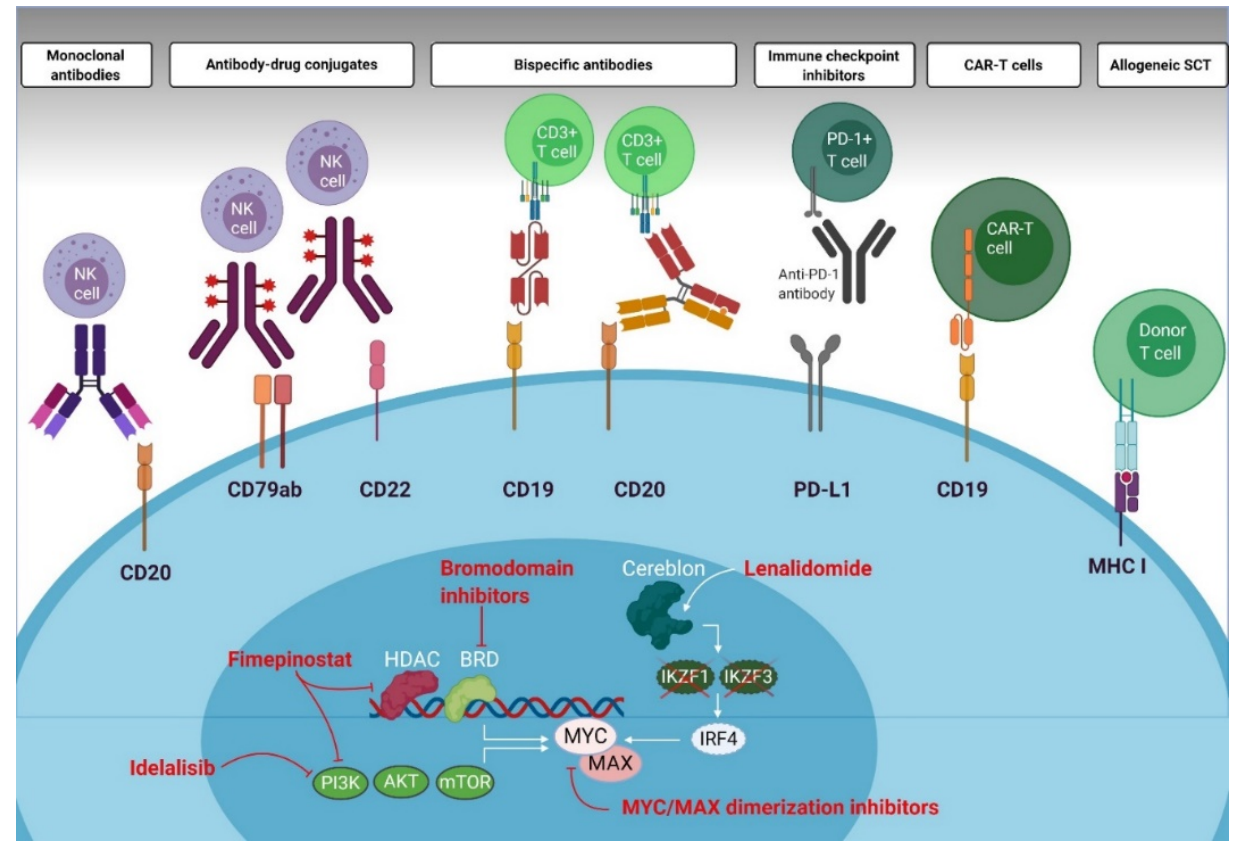

Figure 3. Immunotherapeutic treatment strategies and clinically available MYC modulators in lymphoid malignancies. Antibody-mediated therapies include monoclonal antibodies, antibody-drug conjugates, bispecific antibodies and immune checkpoint inhibitors. Cellular therapies include CAR-T cell therapy and allogeneic stem cell transplantation. Clinically available MYC modulators are lenalidomide (which reduces MYC protein by stimulating Cereblon, subsequently degrading IKZF1 and IKZF3, followed by downregulation of IRF4), idelalisib (PI3K inhibitor) and fimepinostat (combined PI3K and HDAC inhibitor). Preclinical MYC modulators are bromodomain (BRD) inhibitors (e.g., JQ1) and MYC/MAX dimerization inhibitors.

\subsection{T Cell Engaging and Modulating Therapies}

Bispecific $\mathrm{T}$ cell engager antibodies targeting $\mathrm{T}$ cells to a tumor antigen (CD3xCD19 or CD3xCD20) [159], are currently a promising treatment strategy in lymphoid malignancies [160-162]. Bispecific antibodies targeting other antigens (anti-CD47/CD19 TG-1801 NCT03804996, PD-L1/CD137 
(4-1BB) NCT03922204) are also currently being investigated in various groups of B-NHL in ongoing clinical trials. In a phase II study of blinatumomab (CD3xCD19), one patient with a TH HGBL was included and achieved a complete response [161].

Immune checkpoint inhibitors block the interaction of immune checkpoint receptors, such as PD-1 or CTLA-4, with their ligands, thereby enhancing the amplitude of $\mathrm{T}$ cell activation [163]. Although effective in patients with classical Hodgkin lymphoma [164,165], patients with DLBCL show inferior outcomes towards nivolumab monotherapy as compared with standard treatment. The numbers of patients included are too small to separately evaluate the response of MYC overexpressing patients [166]. Currently, phase II clinical studies are ongoing to investigate the effect of additional PD-1 checkpoint inhibitor nivolumab to standard chemotherapy in MYC overexpressing HGBL (NCT03620578 specifically designed for previously untreated HGBL, NCT03038672 and NCT03749018 including HGBL). First-line administration of pembrolizumab, another PD-1 immune checkpoint inhibitor, showed promising results in combination with R-CHOP in untreated DLBCL patients, irrespective of MYC protein expression [167]. Anti-PD-L1 durvalumab is currently being investigated in combination with R-CHOP with or without lenalidomide in previously untreated DLBCL (NCT03003520).

CD47 blocking immune checkpoint inhibitor Hu5F9-G4 is well tolerated and shows potential effective results in patients with relapsed or refractory DLBCL [168]. Although CD47 is pre-clinically correlated with MYC expression [75], consequences of MYC status on clinical outcome with anti-CD47 antibodies are not yet known [168].

\subsection{Cell-Based Immunotherapies}

In allogeneic stem cell transplantation donor T cells recognize and eradicate lymphoma cells, achieving the immunologic "graft versus tumor" effect. Prospective studies evaluating the role of allogeneic stem cell transplantation for patients with MYC overexpression are lacking. The two largest retrospective studies for relapsed DLBCL patients show different results; in one study, long term survival was lower in MYC overexpressing patients [169]. Another study did not observe any differences in 4-year survival between DLBCL patients with or without MYC overexpression [170].

Over the past decades, the field of cell-based immunotherapy has evolved rapidly with the introduction of $T$ cells engineered to express a chimeric antigen receptor (CAR) towards a specific target [171]. Recently, CAR T cells targeting CD19 on B cells have been developed [171]. One preclinical study showed a positive correlation between MYC and CD19 expression. [172], suggesting beneficial effects of CD19 CAR T cell therapy in HGBL patients.

Three independent clinical trials investigated the effect of different CD19 targeting CAR T products in DLBCL and reported outcomes of patients with MYC overexpressing lymphomas as subgroups [173-175]. In summary, no differences in MYC overexpressing patients compared with patients with normal MYC expression were observed regarding response and survival with a median follow up of 28, 16 and 18 months, respectively [173-175]. These results suggest that CAR T cell therapies might overcome the negative effects of MYC overexpression. Efficacy of novel CAR T cells targeting other antigens, such as CD22, CD30 and CD79b [176-181] and innate immunity-mediated CAR NK cells [182] on MYC overexpressing lymphomas are under investigation.

\section{Conclusions and Perspectives}

MYC regulates several aspects of normal immune cell development and can drive lymphomagenesis upon oncogenic transformation. In this review, we described the complex role of MYC overexpression on malignant B cells in the regulation of anti-tumor immune responses and lymphoma immune evasion. In lymphoid malignancies, most studies demonstrate that MYC overexpression negatively affects antigen presentation, $\mathrm{T}$ cell recognition and $\mathrm{T}$ cell and NK cell-mediated cytotoxicity, resulting in lymphoma immune evasion. These findings are largely comparable with the effects of MYC on anti-tumor immune responses across different types of 
cancer [183]. Therefore, MYC modulation has the potential to enhance anti-tumor immune responses. However, we also discussed the consequences of MYC modulation for immune effector cells. MYC is important for differentiation and proliferation of T cells $[28,184,185]$ and for glycolysis, metabolic reprogramming and cell cycle re-entry of activated T cells [26,186,187]. In NK cells, MYC activates receptors on NK cells that regulate NK cell activation and tolerance [188] and MYC drives NK cell expansion during antitumor immunity [189]. As a consequence, beneficial effects of MYC downregulation in malignant target cells may be overshadowed by the effects of MYC downregulation in immune effector cells, reducing their cytotoxic anti-tumor immune responses. Due to the complex effects of MYC deregulation on immune responses, important unanswered questions, especially regarding the effects of MYC on PD-L1, NK cells and the tumor microenvironment remain.

Of all immunotherapeutic strategies, CAR T cell therapy seems to circumvent the negative effects of MYC on immune effector cells. Indeed, three studies demonstrated no inferior outcomes for MYC overexpressing DLBCL patients that received CD19 CAR T cell therapy $[173,174,190]$.

To guide future treatment approaches, further research is needed to elucidate the role of MYC on immune responses in MYC overexpressing lymphomas. So far, in most clinical studies reviewed here, the outcome of patients with and without MYC overexpression was not reported separately, which we would highly recommend doing in future studies. At present, for patients with MYC overexpression, cellular immunotherapies seem most promising. Ideally, these therapies are combined with MYC modulators that improve immunogenicity and facilitate apoptosis. However, current available MYC modulators compromise effector cell function. We expect that more insight into the downstream MYC signaling events playing key roles in immune escape, may facilitate the development of successful cellular immunotherapy approaches that could more specifically exploit the MYC-induced immune escape.

Author Contributions: Conceptualization A.V.d.J., T.M. and M.E.D.C.; literature search A.V.d.J. and B.S.; writing—original draft preparation, A.V.d.J., B.S.; writing—review and editing, A.V.d.J., T.M., M.G.M.R., B.S. and M.E.D.C.; visualization, A.V.d.J.; supervision, M.E.D.C. All authors have read and agreed to the published version of the manuscript.

Funding: This research received no external funding.

Conflicts of Interest: Authors declare no conflict of interest; A.V.d.J. and M.G.M.R. have nothing to disclose. T.M. received research support from Janssen Pharmaceuticals, Novartis, Celgene, Bristol-Myers Squibb, Amgen, Aduro and Onkimmune; B.S. received research funding from Dutch Cancer Society (KWF Kankerbestrijding, grant 11137); M.E.D.C. received research funding from BMS, Celgene, Gilead and GenMab.

\section{References}

1. Swerdlow, S.H.; Campo, E.; Pileri, S.A.; Harris, N.L.; Stein, H.; Siebert, R.; Advani, R.; Ghielmini, M.; Salles, G.A.; Zelenetz, A.D.; et al. The 2016 revision of the World Health Organization classification of lymphoid neoplasms. Blood 2016, 127, 2375-2390. [CrossRef] [PubMed]

2. Cerhan, J.R. Aggressive Lymphomas; Lenz, G., Salles, G., Eds.; Springer: München, Germany, 2019.

3. Horn, H.; Ziepert, M.; Becher, C.; Barth, T.F.; Bernd, H.W.; Feller, A.C.; Klapper, W.; Hummel, M.; Stein, H.; Hansmann, M.L.; et al. MYC status in concert with BCL2 and BCL6 expression predicts outcome in diffuse large B-cell lymphoma. Blood 2013, 121, 2253-2263. [CrossRef] [PubMed]

4. Sewastianik, T.; Prochorec-Sobieszek, M.; Chapuy, B.; Juszczynski, P. MYC deregulation in lymphoid tumors: Molecular mechanisms, clinical consequences and therapeutic implications. Biochim. Biophys. Acta 2014, 1846, 457-467. [CrossRef] [PubMed]

5. Aukema, S.M.; Siebert, R.; Schuuring, E.; van Imhoff, G.W.; Kluin-Nelemans, H.C.; Boerma, E.J.; Kluin, P.M. Double-hit B-cell lymphomas. Blood 2011, 117, 2319-2331. [CrossRef] [PubMed]

6. Boerma, E.G.; Siebert, R.; Kluin, P.M.; Baudis, M. Translocations involving 8q24 in Burkitt lymphoma and other malignant lymphomas: A historical review of cytogenetics in the light of todays knowledge. Leukemia 2009, 23, 225-234. [CrossRef]

7. Riedell, P.A.; Smith, S.M. Double hit and double expressors in lymphoma: Definition and treatment. Cancer 2018, 124, 4622-4632. [CrossRef] 
8. Ennishi, D.; Jiang, A.; Boyle, M.; Collinge, B.; Grande, B.M.; Ben-Neriah, S.; Rushton, C.; Tang, J.; Thomas, N.; Slack, G.W.; et al. Double-Hit Gene Expression Signature Defines a Distinct Subgroup of Germinal Center B-Cell-Like Diffuse Large B-Cell Lymphoma. J. Clin. Oncol. 2018, 37, 190-201. [CrossRef]

9. Sha, C.; Barrans, S.; Cucco, F.; Bently, M.A.; Care, M.A.; Cummin, T.; Kennedy, H.; Thompson, J.S.; Uddin, R.; Worrillow, L.; et al. Molecular High-Grade B-Cell Lymphoma: Defining a Poor-Risk Group That Requires Different Approaches to Therapy. J. Clin. Oncol. 2018, 37, 202-212. [CrossRef]

10. Coiffier, B.L.E.; Briere, J.; Herbrecht, R.; Tilly, H.; Bouabdallah, R.; Morel, P.; Van den Neste, E.; Salles, G.; Gaulard, P.; Reyes, F.; et al. CHOP Chemotherapy Plus Rituximab Compared with CHOP Alone in Elderly Patients with Diffuse Large B-Cell Kymphoma. N. Engl. J. Med. 2002, 346, 235-242. [CrossRef]

11. Savage, K.J.; Johnson, N.A.; Ben-Neriah, S.; Connors, J.M.; Sehn, L.H.; Farinha, P.; Horsman, D.E.; Gascoyne, R.D. MYC gene rearrangements are associated with a poor prognosis in diffuse large B-cell lymphoma patients treated with R-CHOP chemotherapy. Blood 2009, 114, 3533-3537. [CrossRef]

12. Barrans, S.; Crouch, S.; Smith, A.; Turner, K.; Owen, R.; Patmore, R.; Roman, E.; Jack, A. Rearrangement of MYC is associated with poor prognosis in patients with diffuse large B-cell lymphoma treated in the era of rituximab. J. Clin. Oncol. 2010, 28, 3360-3365. [CrossRef] [PubMed]

13. Oki, Y.; Noorani, M.; Lin, P.; Davis, R.E.; Neelapu, S.S.; Ma, L.; Ahmed, M.; Rodriguez, M.A.; Hagemeister, F.B.; Fowler, N.; et al. Double hit lymphoma: The MD Anderson Cancer Center clinical experience. Br. J. Haematol. 2014, 166, 891-901. [CrossRef] [PubMed]

14. Petrich, A.M.; Gandhi, M.; Jovanovic, B.; Castillo, J.J.; Rajguru, S.; Yang, D.T.; Shah, K.A.; Whyman, J.D.; Lansigan, F.; Hernandez-Ilizaliturri, F.J.; et al. Impact of induction regimen and stem cell transplantation on outcomes in double-hit lymphoma: A multicenter retrospective analysis. Blood 2014, 124, 2354-2361. [CrossRef] [PubMed]

15. Dunleavy, K.; Fanale, M.A.; Abramson, J.S.; Noy, A.; Caimi, P.F.; Pittaluga, S.; Parekh, S.; Lacasce, A.; Hayslip, J.W.; Jagadeesh, D.; et al. Dose-adjusted EPOCH-R (etoposide, prednisone, vincristine, cyclophosphamide, doxorubicin, and rituximab) in untreated aggressive diffuse large B-cell lymphoma with MYC rearrangement: A prospective, multicentre, single-arm phase 2 study. Lancet Haematol. 2018, 5, e609-e617. [CrossRef]

16. Rosenwald, A.; Bens, S.; Advani, R.; Barrans, S.; Copie-Bergman, C.; Elsensohn, M.-H.; Natkunam, Y.; Calaminici, M.; Sander, B.; Baia, M.; et al. Prognostic Significance of MYC Rearrangement and Translocation Partner in Diffuse Large B-Cell Lymphoma: A Study by the Lunenburg Lymphoma Biomarker Consortium. J. Clin. Oncol. 2019, 37, 3359-3368. [CrossRef]

17. Davies, A. Tailoring front-line therapy in diffuse large B-cell lymphoma: Who should we treat differently? Hematol. Am. Soc. Hematol. Educ. Program 2017, 1, 284-294. [CrossRef]

18. Sesques, P.; Johnson, N.A. Approach to the diagnosis and treatment of high-grade B-cell lymphomas with MYC and BCL2 and/or BCL6 rearrangements. Blood 2017, 129, 280-288. [CrossRef]

19. Jacobson, C.A.; Armand, P. Immunotherapy in aggressive B-cell lymphomas. Best Pract. Res. Clin. Haematol. 2018, 31, 299-305. [CrossRef] [PubMed]

20. Love, C.; Sun, Z.; Jima, D.; Li, G.; Zhang, J.; Miles, R.; Richards, K.L.; Dunphy, C.H.; Choi, W.W.L.; Srivastava, G.; et al. The genetic landscape of mutations in Burkitt lymphoma. Nat. Genet. 2012, 44, 1321-1325. [CrossRef]

21. Blackwell, T.K.; Kretzner, L.; Blackwood, E.M.; Eisenman, R.N.; Weintraub, H. Sequence-specific DNA binding by the c-Myc protein. Science 1990, 250, 1149-1151. [CrossRef]

22. Patel, J.H.; Loboda, A.P.; Showe, M.K.; Showe, L.C.; McMahon, S.B. Analysis of genomic targets reveals complex functions of MYC. Nat. Rev. 2004, 4, 652-658. [CrossRef] [PubMed]

23. Dang, C.V.; O’Donnell, K.A.; Zeller, K.I.; Nguyen, T.; Osthus, R.C.; Li, F. The c-Myc target gene network. Semin. Cancer Biol. 2006, 16, 253-264. [CrossRef] [PubMed]

24. Miller, D.M.; Thomas, S.D.; Islam, A.; Muench, D.; Sedoris, K. c-Myc and cancer metabolism. Clin. Cancer Res. 2012, 18, 5546-5553. [CrossRef] [PubMed]

25. Amati, B.; Dalton, S.; Brooks, M.W.; Littlewood, T.D.; Evan, G.I.; Land, H. Transcriptational Activity by the Human c-Myc Oncoprotein in Yeast Requires Interaction with Max. Nature 1992, 359, 423-426. [CrossRef] [PubMed]

26. Siska, P.J.; Rathmell, J.C. T cell metabolic fitness in antitumor immunity. Trends Immunol. 2015, 36, $257-264$. [CrossRef] 
27. Gnanaprakasam, J.N.; Wang, R. MYC in Regulating Immunity: Metabolism and Beyond. Genes 2017, 8, 88. [CrossRef]

28. Gnanaprakasam, J.N.R.; Sherman, J.W.; Wang, R. MYC and HIF in shaping immune response and immune metabolism. Cytokine Growth Factor Rev. 2017, 35, 63-70. [CrossRef]

29. Kim, T.W.; Hong, S.; Lin, Y.; Murat, E.; Joo, H.; Kim, T.; Pascual, V.; Liu, Y.J. Transcriptional Repression of IFN Regulatory Factor 7 by MYC Is Critical for Type I IFN Production in Human Plasmacytoid Dendritic Cells. J. Immunol. 2016, 197, 3348-3359. [CrossRef]

30. Kurosaki, T. Regulation of B cell fates by BCR signaling components. Curr. Opin. Immunol. 2002, 14, 341-347. [CrossRef]

31. Kraus, M.; Alimzhanov, M.B.; Rajewsky, N.; Rajewsky, K. Survival of resting mature B lymphocytes depends on BCR signaling via the Igalpha/beta heterodimer. Cell 2004, 117, 787-800. [CrossRef]

32. Küppers, R. Mechanisms of B-cell lymphoma pathogenesis. Nat. Rev. Cancer 2005, 5, 251-262. [CrossRef] [PubMed]

33. Leone, G.; DeGregori, J.; Sears, R.; Jakoi, L.; Nevins, J.R. Myc and Ras collaborate in inducing accumulation of active cyclin E/Cdk2 and E2F. Nature 1997, 387, 422-426. [CrossRef]

34. Iritani, B.M.; Eisenman, R.N. c-MYC enhances protein synthesis and cell size during B lymphocyte development. Proc. Natl. Acad. Sci. USA 1999, 96, 13180-13185. [CrossRef] [PubMed]

35. Habib, T.; Park, H.; Tsang, M.; de Alboran, I.M.; Nicks, A.; Wilson, L.; Knoepfler, P.S.; Andrews, S.; Rawlings, D.J.; Eisenman, R.N.; et al. Myc stimulates B lymphocyte differentiation and amplifies calcium signaling. J. Cell Biol. 2007, 179, 717-731. [CrossRef] [PubMed]

36. Moreno de Alboran, I.; O’Hagan, R.C.; Gärtner, F.; Malynn, B.; Davidson, L.; Rickert, R.; Rajewsky, K.; DePinho, R.A.; Alt, F.W. Analysis of C-MYC function in Normal Cells via Conditional Gene-Targeted Mutation. Immunity 2001, 14, 45-55. [CrossRef]

37. Vallespinos, M.; Fernandez, D.; Rodriguez, L.; Alvaro-Blanco, J.; Baena, E.; Ortiz, M.; Dukovska, D.; Martinez, D.; Rojas, A.; Campanero, M.R.; et al. B Lymphocyte commitment program is driven by the proto-oncogene c-Myc. J. Immunol. 2011, 186, 6726-6736. [CrossRef] [PubMed]

38. Dominguez-Sola, D.; Victora, G.D.; Ying, C.Y.; Phan, R.T.; Saito, M.; Nussenzweig, M.C.; Dalla-Favera, R. The proto-oncogene MYC is required for selection in the germinal center and cyclic reentry. Nat. Immunol. 2012, 13, 1083-1091. [CrossRef]

39. de Barrios, O.; Meler, A.; Parra, M. MYC's Fine Line Between B Cell Development and Malignancy. Cells 2020, 9, 523. [CrossRef]

40. Murn, J.; Mlinaric-Rascan, I.; Vaigot, P.; Alibert, O.; Frouin, V.; Gidrol, X. A Myc-regulated transcriptional network controls B-cell fate in response to BCR triggering. BMC Genom. 2009, 10, 323. [CrossRef]

41. Korac, P.; Dotlic, S.; Matulic, M.; Zajc Petranovic, M.; Dominis, M. Role of MYC in B Cell Lymphomagenesis. Genes 2017, 8, 115. [CrossRef]

42. Lin, Y.; Wong, K.K.; Calame, K. Repression of c-myc Transcription by Blimp-1, an Inducer of Terminal B Cell Differentiation. Science 1997, 267, 596-599. [CrossRef] [PubMed]

43. Rooney, C.M.; Rowe, M.; Wallace, L.E.; Rickinson, A.B. Epstein-Barr virus-positive Burkitt's lymphoma cells not recognized by virus-specific T cell surveillance. Nature 1985, 317, 629-631. [CrossRef] [PubMed]

44. Torsteinsdottir, S.; Masucci, M.G.; Ehlin-Henrikson, B.; Brautbar, C.; Ben Bassat, H.; Klein, G.; Klein, E. Differentiation-dependent sensitivity of human B-cell-derived lines to major histocompatibility complex-restricted T-cell cytotoxicity. Proc. Natl. Acad. Sci. USA 1986, 83, 5620-5624. [CrossRef]

45. Staege, M.S.; Lee, S.P.; Frisan, T.; Mautner, J.; Scholz, S.; Pajic, A.; Rickinson, A.; Masucci, M.G.; Polack, A.; Bornkamm, G.W. MYC overexpression imposes a nonimmunogenic phenotype on Epstein-Barr virus-nfected B cells. Proc. Natl. Acad. Sci. USA 2002, 99, 4550-4555. [CrossRef] [PubMed]

46. Versteeg, R.; Noordermeer, I.A.; Krüse-Wolters, M.; Ruiter, D.J.; Schier, P.I. C-myc down-regulates class I HLA expression in human melanomas. EMBO J. 1988, 7, 1023-1029. [CrossRef]

47. Peltenburg, L.T.C.; Dee, R.; Schier, P.I. Downregulation HLA Class I expression by c-MYC in human melanoma is independent of enhancer A. Nucleic Acids Res. 1993, 21, 1179-1185. [CrossRef]

48. Ock, C.Y.; Hwang, J.E.; Keam, B.; Kim, S.B.; Shim, J.J.; Jang, H.J.; Park, S.; Sohn, B.H.; Cha, M.; Ajani, J.A.; et al. Genomic landscape associated with potential response to anti-CTLA-4 treatment in cancers. Nat. Commun. 2017, 8, 1050. [CrossRef] 
49. Kortlever, R.M.; Sodir, N.M.; Wilson, C.H.; Burkhart, D.L.; Pellegrinet, L.; Brown Swigart, L.; Littlewood, T.D.; Evan, G.I. Myc Cooperates with Ras by Programming Inflammation and Immune Suppression. Cell 2017, 171, 1301-1315.e1314. [CrossRef]

50. Topper, M.J.; Vaz, M.; Chiappinelli, K.B.; DeStefano Shields, C.E.; Niknafs, N.; Yen, R.C.; Wenzel, A.; Hicks, J.; Ballew, M.; Stone, M.; et al. Epigenetic Therapy Ties MYC Depletion to Reversing Immune Evasion and Treating Lung Cancer. Cell 2017, 171, 1284-1300 e1221. [CrossRef]

51. God, J.M.; Cameron, C.; Figueroa, J.; Amria, S.; Hossain, A.; Kempkes, B.; Bornkamm, G.W.; Stuart, R.K.; Blum, J.S.; Haque, A. Elevation of c-MYC disrupts HLA class II-mediated immune recognition of human B cell tumors. J. Immunol. 2015, 194, 1434-1445. [CrossRef]

52. Walling, B.L.; Kim, M. LFA-1 in T Cell Migration and Differentiation. Front. Immunol. 2018, 9, 952. [CrossRef] [PubMed]

53. Inghirami, G.; Grignani, F.; Sternas, L.; Lombardi, L.; Knowles, D.M.; Dalla-Favera, R. Down-regulation of LFA-1 Adhesion Receptors by C-myc oncogene in Human B Lymphoblastoid Cells. Science 1990, 250, 682-686. [CrossRef] [PubMed]

54. Polack, A.; Hörtnagel, K.; Pajic, A.; Christoph, B.; Baier, B.; Falk, M.; Mautner, J.; Geltinger, C.; Bornkamm, G.W.; Kempkes, B. c-myc activation renders proliferation of Epstein-Barr virus (EBV)-transformed cells independent of EBV nuclear antigen 2 and latent membrane protein 1. Proc. Natl. Acad. Sci. USA 1996, 93, 10411-10416. [CrossRef] [PubMed]

55. David, A.; Arnaud, N.; Fradet, M.; Lascaux, H.; Ouk-Martin, C.; Gachard, N.; Zimber-Strobl, U.; Feuillard, J.; Faumont, N. c-Myc dysregulation is a co-transforming event for nuclear factor-kappaB activated B cells. Haematologica 2017, 102, 883-894. [CrossRef]

56. Schlee, M.; Schuhmacher, M.; Hölzel, M.; Laux, G.; Bornkamm, G.W. c-MYC Impairs Immunogenicity of Human B Cells. Adv. Cancer Res. 2007, 97, 167-188. [CrossRef]

57. Pajic, A.; Staege, M.S.; Dudziak, D.; Schuhmacher, M.; Spitkovsky, D.; Eissner, G.; Brielmeier, M.; Polack, A.; Bornkamm, G.W. Antagonistic effects of c-myc and Epstein-barr virus latent genes on the phenotype of human B cells. Int. J. Cancer 2001, 93. [CrossRef]

58. Elgueta, R.; Benson, M.J.; de Vries, V.C.; Wasiuk, A.; Guo, Y.; Noelle, R.J. Molecular mechanism and function of CD40/CD40L engagement in the immune system. Immunol. Rev. 2009, 229, 152-172. [CrossRef]

59. Bromley, S.K.; Iaboni, A.; Davis, S.J.; Whitty, A.; Green, J.M.; Shaw, A.S.; Weiss, A.; Dustin, M.L. The immunological synapse and CD28-CD80 interactions. Nat. Immunol. 2001, 2, 1159-1166. [CrossRef]

60. Xu, P.P.; Sun, C.; Cao, X.; Zhao, X.; Dai, H.J.; Lu, S.; Guo, J.J.; Fu, S.J.; Liu, Y.X.; Li, S.C.; et al. Immune Characteristics of Chinese Diffuse Large B-Cell Lymphoma Patients: Implications for Cancer Immunotherapies. EBioMedicine 2018, 33, 94-104. [CrossRef]

61. Chen, L. Co-inhibitory molecules of the B7-CD28 family in the control of T-cell immunity. Nat. Rev. Immunol. 2004, 4, 336-347. [CrossRef]

62. Kiyasu, J.; Miyoshi, H.; Hirata, A.; Arakawa, F.; Ichikawa, A.; Niino, D.; Sugita, Y.; Yufu, Y.; Choi, I.; Abe, Y.; et al. Expression of programmed cell death ligand 1 is associated with poor overall survival in patients with diffuse large B-cell lymphoma. Blood 2015, 126, 2193-2201. [CrossRef]

63. Hu, L.Y.; Xu, X.L.; Rao, H.L.; Chen, J.; Lai, R.C.; Huang, H.Q.; Jiang, W.Q.; Lin, T.Y.; Xia, Z.J.; Cai, Q.Q. Expression and clinical value of programmed cell death-ligand 1 (PD-L1) in diffuse large B cell lymphoma: A retrospective study. Chin. J. Cancer 2017, 36, 94. [CrossRef] [PubMed]

64. Elbaek, M.V.; Pedersen, M.O.; Breinholt, M.F.; Reddy, A.; Love, C.; Clasen-Linde, E.; Knudsen, H.; Nielsen, S.L.; Gang, A.O.; Hogdall, E.; et al. PD-L1 expression is low in large B-cell lymphoma with MYC or double-hit translocation. Hematol. Oncol. 2019, 37, 375-382. [CrossRef] [PubMed]

65. Li, L.; Sun, R.; Miao, Y.; Tran, T.; Adams, L.; Roscoe, N.; Xu, B.; Manyam, G.C.; Tan, X.; Zhang, H.; et al. PD-1/PD-L1 expression and interaction by automated quantitative immunofluorescent analysis show adverse prognostic impact in patients with diffuse large B-cell lymphoma having T-cell infiltration: A study from the International DLBCL Consortium Program. Mod. Pathol. 2019, 32, 741-754. [CrossRef] [PubMed]

66. Godfrey, J.; Tumuluru, S.; Bao, R.; Leukam, M.; Venkataraman, G.; Phillip, J.; Fitzpatrick, C.; McElherne, J.; MacNabb, B.W.; Orlowski, R.; et al. PD-L1 gene alterations identify a subset of diffuse large B-cell lymphoma harboring a T-cell inflamed phenotype. Blood 2019, 133, 2279-2290. [CrossRef] [PubMed] 
67. Wang, W.G.; Jiang, X.N.; Sheng, D.; Sun, C.B.; Lee, J.; Zhou, X.Y.; Li, X.Q. PD-L1 over-expression is driven by B-cell receptor signaling in diffuse large B-cell lymphoma. Lab Investig. 2019, 99, 1418-1427. [CrossRef] [PubMed]

68. Xing, W.; Dresser, K.; Zhang, R.; Evens, A.M.; Yu, H.; Woda, B.A.; Chen, B.J. PD-L1 expression in EBV-negative diffuse large B-cell lymphoma: Clinicopathologic features and prognostic implications. Oncotarget 2016, 7, 55976-55986. [CrossRef]

69. Xu, Y.; Poggio, M.; Jin, H.Y.; Shi, Z.; Forester, C.M.; Wang, Y.; Stumpf, C.R.; Xue, L.; Devericks, E.; So, L.; et al. Translation control of the immune checkpoint in cancer and its therapeutic targeting. Nat. Med. 2019, 25, 301-311. [CrossRef]

70. Pan, Y.; Fei, Q.; Xiong, P.; Yang, J.; Zhang, Z.; Lin, X.; Pan, M.; Lu, F.; Huang, H. Synergistic inhibition of pancreatic cancer with anti-PD-L1 and c-Myc inhibitor JQ1. Oncoimmunology 2019, 8, e1581529. [CrossRef]

71. Kim, E.Y.; Kim, A.; Kim, S.K.; Chang, Y.S. MYC expression correlates with PD-L1 expression in non-small cell lung cancer. Lung Cancer 2017, 110, 63-67. [CrossRef]

72. Liang, M.Q.; Yu, F.Q.; Chen, C. C-Myc regulates PD-L1 expression in esophageal squamous cell carcinoma. Am. J. Transl. Res. 2020, 12, 379-388. [PubMed]

73. Wang, J.; Jia, Y.; Zhao, S.; Zhang, X.; Wang, X.; Han, X.; Wang, Y.; Ma, M.; Shi, J.; Liu, L. BIN1 reverses PD-L1-mediated immune escape by inactivating the c-MYC and EGFR/MAPK signaling pathways in non-small cell lung cancer. Oncogene 2017, 36, 6235-6243. [CrossRef] [PubMed]

74. Sun, L.; Wang, Q.; Chen, B.; Zhao, Y.; Shen, B.; Wang, H.; Xu, J.; Zhu, M.; Zhao, X.; Xu, C.; et al. Gastric cancer mesenchymal stem cells derived IL-8 induces PD-L1 expression in gastric cancer cells via STAT3/mTOR-c-Myc signal axis. Cell Death Dis. 2018, 9, 928. [CrossRef] [PubMed]

75. Casey, S.C.; Tong, L.; Li, Y.; Do, R.; Walz, S.; Fitzgerald, K.N.; Gouw, A.M.; Baylot, V.; Gutgemann, I.; Eilers, M.; et al. MYC regulates the antitumor immune response through CD47 and PD-L1. Science 2016, 352, 227-231. [CrossRef] [PubMed]

76. Hogg, S.J.; Vervoort, S.J.; Deswal, S.; Ott, C.J.; Li, J.; Cluse, L.A.; Beavis, P.A.; Darcy, P.K.; Martin, B.P.; Spencer, A.; et al. BET-Bromodomain Inhibitors Engage the Host Immune System and Regulate Expression of the Immune Checkpoint Ligand PD-L1. Cell Rep. 2017, 18, 2162-2174. [CrossRef] [PubMed]

77. Durand-Panteix, S.; Farhat, M.; Youlyouz-Marfak, I.; Rouaud, P.; Ouk-Martin, C.; David, A.; Faumont, N.; Feuillard, J.; Jayat-Vignoles, C. B7-H1, which represses EBV-immortalized B cell killing by autologous T and NK cells, is oppositely regulated by c-Myc and EBV latency III program at both mRNA and secretory lysosome levels. J. Immunol. 2012, 189, 181-190. [CrossRef] [PubMed]

78. Schlee, M.; Holzel, M.; Bernard, S.; Mailhammer, R.; Schuhmacher, M.; Reschke, J.; Eick, D.; Marinkovic, D.; Wirth, T.; Rosenwald, A.; et al. c-MYC activation impairs the NF-kappaB and the interferon response: Implications for the pathogenesis of Burkitt's lymphoma. Int. J. Cancer 2007, 120, 1387-1395. [CrossRef]

79. Ramana, C.V.; Grammatikakis, N.; Chernov, M.; Nguyen, H.; Goh, K.C.; Williams, B.R.G.; Stark, G.R. Regulation of $c$-myc expression by IFN- $\gamma$ through Stat1-dependent and -independent pathways. EMBO J. 2000, 19, 263-272. [CrossRef]

80. Li, W.; Gupta, S.K.; Han, W.; Kundson, R.A.; Nelson, S.; Knutson, D.; Greipp, P.T.; Elsawa, S.F.; Sotomayor, E.M.; Gupta, M. Targeting MYC activity in double-hit lymphoma with MYC and BCL2 and/or BCL6 rearrangements with epigenetic bromodomain inhibitors. J. Hematol. Oncol. 2019, 12, 73. [CrossRef]

81. Xue, T.; Wang, W.G.; Zhou, X.Y.; Li, X.Q. EBV-positive diffuse large B-cell lymphoma features PD-L1 protein but not mRNA overexpression. Pathology 2018, 50, 725-729. [CrossRef]

82. Zuo, J.; Currin, A.; Griffin, B.D.; Shannon-Lowe, C.; Thomas, W.A.; Ressing, M.E.; Wiertz, E.J.; Rowe, M. The Epstein-Barr virus G-protein-coupled receptor contributes to immune evasion by targeting MHC class I molecules for degradation. PLoS Pathog. 2009, 5, e1000255. [CrossRef] [PubMed]

83. Rowe, M.; Zuo, J. Immune responses to Epstein-Barr virus: Molecular interactions in the virus evasion of CD8+ T cell immunity. Microbes Infect. 2010, 12, 173-181. [CrossRef] [PubMed]

84. Kwon, D.; Kim, S.; Kim, P.J.; Go, H.; Nam, S.J.; Paik, J.H.; Kim, Y.A.; Kim, T.M.; Heo, D.S.; Kim, C.W.; et al. Clinicopathological analysis of programmed cell death 1 and programmed cell death ligand 1 expression in the tumour microenvironments of diffuse large B cell lymphomas. Histopathology 2016, 68, 1079-1089. [CrossRef] [PubMed] 
85. Anastasiadou, E.; Stroopinsky, D.; Alimperti, S.; Jiao, A.L.; Pyzer, A.R.; Cippitelli, C.; Pepe, G.; Severa, M.; Rosenblatt, J.; Etna, M.P.; et al. Epstein-Barr virus-encoded EBNA2 alters immune checkpoint PD-L1 expression by downregulating miR-34a in B-cell lymphomas. Leukemia 2019, 33, 132-147. [CrossRef]

86. Kärre, K.; Ljunggren, H.G.; Piontek, G.; Kiessling, R. Selective rejection of H-2-deficient lymphoma variants suggests alternative immune defence strategy. Nature 1986, 319, 675-678. [CrossRef]

87. Bern, M.D.; Parikh, B.A.; Yang, L.; Beckman, D.L.; Poursine-Laurent, J.; Yokoyama, W.M. Inducible down-regulation of MHC class I results in natural killer cell tolerance. J. Exp. Med. 2019, 216, 99-116. [CrossRef]

88. Swaminathan, S.; Hansen, A.S.; Heftdal, L.D.; Dhanasekaran, R.; Deutzmann, A.; Fernandez, W.D.M.; Liefwalker, D.F.; Horton, C.; Mosley, A.; Liebersbach, M.; et al. MYC functions as a switch for natural killer cell-mediated immune surveillance of lymphoid malignancies. Nat. Commun. 2020, 11, 2860. [CrossRef]

89. Textor, S.; Bossler, F.; Henrich, K.O.; Gartlgruber, M.; Pollmann, J.; Fiegler, N.; Arnold, A.; Westermann, F.; Waldburger, N.; Breuhahn, K.; et al. The proto-oncogene Myc drives expression of the NK cell-activating NKp30 ligand B7-H6 in tumor cells. Oncoimmunology 2016, 5, e1116674. [CrossRef]

90. Yetil, A.; Anchang, B.; Gouw, A.M.; Adam, S.J.; Zabuawala, T.; Parameswaran, R.; Van Riggelen, J.; Plevritis, S.; Felsher, D.W. p19ARF is a critical mediator of both cellular senescence and an innate immune response associated with MYC inactivation in mouse model of acute leukemia. Oncotarget 2015, 6, 3563-3577. [CrossRef]

91. Jaime-Sanchez, P.; Catalan, E.; Uranga-Murillo, I.; Aguilo, N.; Santiago, L.; Lanuza, P.M.; de Miguel, D.; Arias, M.A.; Pardo, J. Antigen-specific primed cytotoxic T cells eliminate tumour cells in vivo and prevent tumour development, regardless of the presence of anti-apoptotic mutations conferring drug resistance. Cell Death Differ. 2018, 25, 1536-1548. [CrossRef]

92. Klapproth, K.; Wirth, T. Advances in the understanding of MYC-induced lymphomagenesis. Br. J. Haematol. 2010, 149, 484-497. [CrossRef] [PubMed]

93. Askew, D.S.; Ashmun, R.A.; Simmons, B.C.; Cleveland, J.L. Constitutive c-myc expression in an IL-3-dependent myeloid cell line suppresses cell cycle arrest and accelerates apoptosis. Oncogene 1991, 6, 1915-1922. [PubMed]

94. Evan, G.I.; Wyllie, A.H.; Gilbert, C.S.; Littlewood, T.D.; Land, H.; Brooks, M.; Waters, C.M.; Penn, L.Z.; Hancock, D.C. Induction of apoptosis in fibroblasts by c-myc protein. Cell 1992, 69, 119-128. [CrossRef]

95. Vecchio, E.; Fiume, G.; Correnti, S.; Romano, S.; Iaccino, E.; Mimmi, S.; Maisano, D.; Nistico, N.; Quinto, I. Insights about MYC and Apoptosis in B-Lymphomagenesis: An Update from Murine Models. Int. J. Mol. Sci. 2020, 21, 4265. [CrossRef]

96. Eischen, C.M.; Weber, J.D.; Roussel, M.F.; Sherr, C.J.; Cleveland, J.L. Disrupton of the ARF-Mdm2-p53 tumor suppressor pathway in Myc-induced lymphomagenesis. Genes Dev. 1999, 13, 2658-2669. [CrossRef]

97. McMahon, S.B. MYC and the control of apoptosis. Cold Spring Harb. Perspect Med. 2014, 4, a014407. [CrossRef]

98. Nguyen, H.V.; Vandenberg, C.J.; Ng, A.P.; Robati, M.R.; Anstee, A.S.; Rimes, J.; Hawkins, E.D.; Cory, S. Development and survival of MYC-driven lymphomas require the MYC antagonist MNT to curb MYC-induced apoptosis. Blood 2020, 135, 1019-1031. [CrossRef]

99. Grabow, S.; Delbridge, A.R.; Aubrey, B.J.; Vandenberg, C.J.; Strasser, A. Loss of a Single Mcl-1 Allele Inhibits MYC-Driven Lymphomagenesis by Sensitizing Pro-B Cells to Apoptosis. Cell Rep. 2016, 14, 2337-2347. [CrossRef]

100. Ott, G.; Rosenwald, A.; Campo, E. Understanding MYC-driven aggressive B-cell lymphomas: Pathogenesis and classification. Blood 2013, 122, 3884-3891. [CrossRef]

101. Le, A.; Lane, A.N.; Hamaker, M.; Bose, S.; Gouw, A.; Barbi, J.; Tsukamoto, T.; Rojas, C.J.; Slusher, B.S.; Zhang, H.; et al. Glucose-independent glutamine metabolism via TCA cycling for proliferation and survival in B cells. Cell Metab. 2012, 15, 110-121. [CrossRef]

102. Kim, J.W.; Gao, P.; Liu, Y.C.; Semenza, G.L.; Dang, C.V. Hypoxia-inducible factor 1 and dysregulated c-Myc cooperatively induce vascular endothelial growth factor and metabolic switches hexokinase 2 and pyruvate dehydrogenase kinase 1. Mol. Cell Biol. 2007, 27, 7381-7393. [CrossRef] [PubMed]

103. Mushtaq, M.; Darekar, S.; Klein, G.; Kashuba, E. Different Mechanisms of Regulation of the Warburg Effect in Lymphoblastoid and Burkitt Lymphoma Cells. PLoS ONE 2015, 10, e0136142. [CrossRef] [PubMed] 
104. Kim, J.W.; Zeller, K.I.; Wang, Y.; Jegga, A.G.; Aronow, B.J.; O’Donnell, K.A.; Dang, C.V. Evaluation of myc E-box phylogenetic footprints in glycolytic genes by chromatin immunoprecipitation assays. Mol. Cell Biol. 2004, 24, 5923-5936. [CrossRef] [PubMed]

105. Osthus, R.C.; Shim, H.; Kim, S.; Li, Q.; Reddy, R.; Mukherjee, M.; Xu, Y.; Wonsey, D.; Lee, L.A.; Dang, C.V. Deregulation of glucose transporter 1 and glycolytic gene expression by c-Myc. J. Biol. Chem. 2000, 275, 21797-21800. [CrossRef] [PubMed]

106. Shim, H.; Dolde, C.; Lewis, B.C.; Wu, C.-S.; Dang, G.; Jungmann, R.A.; Dalla-Favera, R.; Dang, C.V. c-Myc transactivation of LHD-A: Implications for tumor metabolism and growth. Proc. Natl. Acad. Sci. USA 1997, 94, 6658-6663. [CrossRef]

107. Shim, H.; Chun, Y.S.; Lewis, B.C.; Dang, C.V. A unique glucose-dependent apoptotic pathway induced by c-Myc. Proc. Natl. Acad. Sci. USA 1998, 95, 1511-1516. [CrossRef]

108. Lewis, B.C.; Prescott, J.E.; Campbell, S.E.; Shim, H.; Orlowski, R.Z.; Dang, C.V. Tumor Induction by the c-Myc Target Genes rcl and Lactate Dehydrogenase A. Cancer Res. 2000, 60, 6178-6183.

109. David, C.J.; Chen, M.; Assanah, M.; Canoll, P.; Manley, J.L. HnRNP proteins controlled by c-Myc deregulate pyruvate kinase mRNA splicing in cancer. Nature 2010, 463, 364-368. [CrossRef]

110. Gao, P.; Tchernyshyov, I.; Chang, T.C.; Lee, Y.S.; Kita, K.; Ochi, T.; Zeller, K.I.; De Marzo, A.M.; Van Eyk, J.E.; Mendell, J.T.; et al. c-Myc suppression of miR-23a/b enhances mitochondrial glutaminase expression and glutamine metabolism. Nature 2009, 458, 762-765. [CrossRef]

111. Wise, D.R.; DeBerardinis, R.J.; Manusco, A.; Sayed, N.; Zhang, X.Y.; Pfeiffer, H.K.; Nissim, I.; Daikhin, E.; Yudkoff, M.; McMahon, S.B.; et al. Myc regulates a transcriptional program that stimulates mitochondrial glutaminolysis and leads to glutamine addiction. Proc. Natl. Acad. Sci. USA 2008, 105, 18782-18787. [CrossRef]

112. Liu, Y.C.; Li, F.; Handler, J.; Huang, C.R.; Xiang, Y.; Neretti, N.; Sedivy, J.M.; Zeller, K.I.; Dang, C.V. Global regulation of nucleotide biosynthetic genes by c-Myc. PLoS ONE 2008, 3, e2722. [CrossRef] [PubMed]

113. Mannava, S.; Grachtchouk, V.; Wheeler, L.J.; Im, M.; Zhuang, D.; Slavina, E.G.; Mathews, C.K.; Shewach, D.S.; Nikiforov, M.A. Direct role of nucleotide metabolism in C-MYC-dependent proliferation of melanoma cells. Cell Cycle 2008, 7, 2392-2400. [CrossRef] [PubMed]

114. Zeller, K.I.; Zhao, X.; Lee, C.W.H.; Chiu, K.P.; Yao, F.; Yustein, J.; Ooi, H.S.; Orlov, Y.L.; Shahab, A.; Yong, H.C.; et al. Global mapping of c-Myc binding sites and target gene networks in human B cells. Proc. Natl. Acad. Sci. USA 2006, 103, 17834-17839. [CrossRef] [PubMed]

115. Chang, C.H.; Qiu, J.; O'Sullivan, D.; Buck, M.D.; Noguchi, T.; Curtis, J.D.; Chen, Q.; Gindin, M.; Gubin, M.M.; van der Windt, G.J.; et al. Metabolic Competition in the Tumor Microenvironment Is a Driver of Cancer Progression. Cell 2015, 162, 1229-1241. [CrossRef] [PubMed]

116. Fischer, K.; Hoffmann, P.; Voelkl, S.; Meidenbauer, N.; Ammer, J.; Edinger, M.; Gottfried, E.; Schwarz, S.; Rothe, G.; Hoves, S.; et al. Inhibitory effect of tumor cell-derived lactic acid on human T cells. Blood 2007, 109, 3812-3819. [CrossRef]

117. Husain, Z.; Huang, Y.; Seth, P.; Sukhatme, V.P. Tumor-derived lactate modifies antitumor immune response: Effect on myeloid-derived suppressor cells and NK cells. J. Immunol. 2013, 191, 1486-1495. [CrossRef]

118. Brand, A.; Singer, K.; Koehl, G.E.; Kolitzus, M.; Schoenhammer, G.; Thiel, A.; Matos, C.; Bruss, C.; Klobuch, S.; Peter, K.; et al. LDHA-Associated Lactic Acid Production Blunts Tumor Immunosurveillance by T and NK Cells. Cell Metab. 2016, 24, 657-671. [CrossRef]

119. Bohn, T.; Rapp, S.; Luther, N.; Klein, M.; Bruehl, T.J.; Kojima, N.; Aranda Lopez, P.; Hahlbrock, J.; Muth, S.; Endo, S.; et al. Tumor immunoevasion via acidosis-dependent induction of regulatory tumor-associated macrophages. Nat. Immunol. 2018, 19, 1319-1329. [CrossRef]

120. Colegio, O.R.; Chu, N.Q.; Szabo, A.L.; Chu, T.; Rhebergen, A.M.; Jairam, V.; Cyrus, N.; Brokowski, C.E.; Eisenbarth, S.C.; Phillips, G.M.; et al. Functional polarization of tumour-associated macrophages by tumour-derived lactic acid. Nature 2014, 513, 559-563. [CrossRef]

121. Yu, Y.R.; Ho, P.C. Sculpting tumor microenvironment with immune system: From immunometabolism to immunoediting. Clin. Exp. Immunol. 2019, 197, 153-160. [CrossRef]

122. Calcinotto, A.; Filipazzi, P.; Grioni, M.; Iero, M.; De Milito, A.; Ricupito, A.; Cova, A.; Canese, R.; Jachetti, E.; Rossetti, M.; et al. Modulation of microenvironment acidity reverses anergy in human and murine tumor-infiltrating T lymphocytes. Cancer Res. 2012, 72, 2746-2756. [CrossRef] [PubMed] 
123. Klysz, D.; Tai, X.; Robert, P.; Craveiro, M.; Cretenet, G.; Oburoglu, L.; Mongellaz, C.; Floess, S.; Fritz, V.; Matias, M.I.; et al. Glutamine-dependent alpha-ketoglutarate production regulates teh balance between T helper 1 cell and regulatory T cell generation. Sci. Signal. 2015, 8, ra97. [CrossRef] [PubMed]

124. Metzler, B.; Gfeller, P.; Guinet, E. Restricting Glutamine or Glutamine-Dependent Purine and Pyrimidine Syntheses Promotes Human T Cells with High FOXP3 Expression and Regulatory Properties. J. Immunol. 2016, 196, 3618-3630. [CrossRef] [PubMed]

125. Loftus, R.M.; Assmann, N.; Kedia-Mehta, N.; O’Brien, K.L.; Garcia, A.; Gillespie, C.; Hukelmann, J.L.; Oefner, P.J.; Lamond, A.I.; Gardiner, C.M.; et al. Amino acid-dependent cMyc expression is essential for NK cell metabolic and functional responses in mice. Nat. Commun. 2018, 9, 2341. [CrossRef]

126. McKeown, M.R.; Bradner, J.E. Therapeutic strategies to inhibit MYC. Cold Spring Harb. Perspect Med. 2014, 4. [CrossRef]

127. Chen, H.; Liu, H.; Qing, G. Targeting oncogenic Myc as a strategy for cancer treatment. Signal. Transduct Target. Ther. 2018, 3, 5. [CrossRef]

128. Allen-Petersen, B.L.; Sears, R.C. Mission Possible: Advances in MYC Therapeutic Targeting in Cancer. BioDrugs 2019, 33, 539-553. [CrossRef]

129. Liu, Y.; Barta, S.K. Diffuse large B-cell lymphoma: 2019 update on diagnosis, risk stratification, and treatment. Am. J. Hematol. 2019, 94, 604-616. [CrossRef]

130. Filippakopoulos, P.; Qi, J.; Picaud, S.; Shen, Y.; Smith, W.B.; Fedorov, O.; Morse, E.M.; Keates, T.; Hickman, T.T.; Felletar, I.; et al. Selective inhibition of BET bromodomains. Nature 2010, 468, 1067-1073. [CrossRef]

131. Delmore, J.E.; Issa, G.C.; Lemieux, M.E.; Rahl, P.B.; Shi, J.; Jacobs, H.M.; Kastritis, E.; Gilpatrick, T.; Paranal, R.M.; Qi, J.; et al. BET bromodomain inhibition as a therapeutic strategy to target c-Myc. Cell 2011, 146, 904-917. [CrossRef]

132. Abramson, J.S.; Blum, K.A.; Flinn, I.W.; Gutierrez, M.; Goy, A.; Maris, M.; Cooper, M.; O’Meara, M.; Borger, D.; Mertz, J.; et al. BET Inhibitor CPI-0610 Is Well Tolerated and Induces Responses in Diffuse Large B-Cell Lymphoma and Follicular Lymphoma: Preliminary Analysis of an Ongoing Phase 1 Study. Blood 2015, 126, 1491. [CrossRef]

133. Bandukwala, H.S.; Gagnon, J.; Togher, S.; Greenbaum, J.A.; Lamperti, E.D.; Parr, N.J.; Molesworth, A.M.; Smithers, N.; Lee, K.; Witherington, J.; et al. Selective inhibition of CD4+ T-cell cytokine production and autoimmunity by BET protein and c-Myc inhibitors. Proc. Natl. Acad. Sci. USA 2012, 109, 14532-14537. [CrossRef] [PubMed]

134. Georgiev, P.; Wang, Y.; Muise, E.S.; Bandi, M.L.; Blumenschein, W.; Sathe, M.; Pinheiro, E.M.; Shumway, S.D. BET Bromodomain Inhibition Suppresses Human T Cell Function. Immunohorizons 2019, 3, 294-305. [CrossRef] [PubMed]

135. Gibbons, H.R.; Mi, D.J.; Farley, V.M.; Esmond, T.; Kaood, M.B.; Aune, T.M. Bromodomain inhibitor JQ1 reversibly blocks IFN-gamma production. Sci. Rep. 2019, 9, 10280. [CrossRef] [PubMed]

136. Kagoya, Y.; Nakatsugawa, M.; Yamashita, Y.; Ochi, T.; Guo, T.; Anczurowski, M.; Saso, K.; Butler, M.O.; Arrowsmith, C.H.; Hirano, N. BET bromodomain inhibition enhances T cell persistence and function in adoptive immunotherapy models. J. Clin. Investig. 2016, 126, 3479-3494. [CrossRef]

137. Hoxhaj, G.; Manning, B.D. The PI3K-AKT network at the interface of oncogenic signalling and cancer metabolism. Nat. Rev. Cancer 2020, 20, 74-88. [CrossRef]

138. Xie, S.; Chen, M.; Yan, B.; He, X.; Chen, X.; Li, D. Identification of a role for the PI3K/AKT/mTOR signaling pathway in innate immune cells. PLoS ONE 2014, 9, e94496. [CrossRef]

139. Han, J.M.; Patterson, S.J.; Levings, M.K. The Role of the PI3K Signaling Pathway in CD4(+) T Cell Differentiation and Function. Front. Immunol. 2012, 3, 245. [CrossRef]

140. So, L.; Fruman, D.A. PI3K signalling in B- and T-lymphocytes: New developments and therapeutic advances. Biochem. J. 2012, 442, 465-481. [CrossRef]

141. Ali, A.K.; Nandagopal, N.; Lee, S.H. IL-15-PI3K-AKT-mTOR: A Critical Pathway in the Life Journey of Natural Killer Cells. Front. Immunol. 2015, 6, 355. [CrossRef]

142. Deng, C.; Lipstein, M.R.; Scotto, L.; Jireau Serrano, X.O.; Mangone, M.A.; Li, S.; Vendome, J.; Hao, Y.; Xu, X.; Deng, S.X.; et al. Silencing c-Myc Translation as a Therapeutic Strategy through Targeting PI3K Delta and CK1 Epsilon in Hematological Malignancies. Blood 2016, 129, 88-99. [CrossRef] [PubMed] 
143. Sun, K.; Atoyan, R.; Borek, M.A.; Dellarocca, S.; Samson, M.E.; Ma, A.W.; Xu, G.X.; Patterson, T.; Tuck, D.P.; Viner, J.L.; et al. Dual HDAC and PI3K Inhibitor CUDC-907 Downregulates MYC and Suppresses Growth of MYC-dependent Cancers. Mol. Cancer Ther. 2017, 16, 285-299. [CrossRef] [PubMed]

144. Oki, Y.; Kelly, K.R.; Flinn, I.; Patel, M.R.; Gharavi, R.; Ma, A.; Parker, J.; Hafeez, A.; Tuck, D.; Younes, A. CUDC-907 in relapsed/refractory diffuse large B-cell lymphoma, including patients with MYC-alterations: Results from an expanded phase I trial. Haematologica 2017, 102, 1923-1930. [CrossRef] [PubMed]

145. Jackstadt, R.; Hermeking, H. MicroRNAs as regulators and mediators of c-MYC function. Biochim. Biophys. Acta 2015, 1849, 544-553. [CrossRef] [PubMed]

146. Soucek, L.; Helmer-Citterich, M.; Sacco, A.; Jucker, R.; Cesareni, G.; Nasi, S. Design and properties of a Myc derivative that efficiently homodimerizes. Oncogene 1998, 17, 2463-2472. [CrossRef] [PubMed]

147. Beaulieu, M.E.; Jauset, T.; Masso-Valles, D.; Martinez-Martin, S.; Rahl, P.; Maltais, L.; Zacarias-Fluck, M.F.; Casacuberta-Serra, S.; Serrano Del Pozo, E.; Fiore, C.; et al. Intrinsic cell-penetrating activity propels Omomyc from proof of concept to viable anti-MYC therapy. Sci. Transl. Med. 2019, 11. [CrossRef] [PubMed]

148. Masso-Valles, D.; Soucek, L. Blocking Myc to Treat Cancer: Reflecting on Two Decades of Omomyc. Cells 2020, 9, 883. [CrossRef]

149. Yin, X.; Giap, C.; Lazo, J.S.; Prochownik, E.V. Low molecular weight inhibitors of Myc-Max interaction and function. Oncogene 2003, 22, 6151-6159. [CrossRef]

150. Gomez-Curet, I.; Perkins, R.S.; Bennett, R.; Feidler, K.L.; Dunn, S.P.; Krueger, L.J. c-Myc inhibition negatively impacts lymphoma growth. J. Pediatr. Surg. 2006, 41, 207-211. [CrossRef]

151. Struntz, N.B.; Chen, A.; Deutzmann, A.; Wilson, R.M.; Stefan, E.; Evans, H.L.; Ramirez, M.A.; Liang, T.; Caballero, F.; Wildschut, M.H.E.; et al. Stabilization of the Max Homodimer with a Small Molecule Attenuates Myc-Driven Transcription. Cell Chem. Biol. 2019, 26, 711-723.e714. [CrossRef]

152. Gallant, P.; Steiger, D. Myc's secret life without Max. Cell Cycle 2009, 8, 3848-3853. [CrossRef]

153. Han, H.; Jain, A.D.; Truica, M.I.; Izquierdo-Ferrer, J.; Anker, J.F.; Lysy, B.; Sagar, V.; Luan, Y.; Chalmers, Z.R.; Unno, K.; et al. Small-Molecule MYC Inhibitors Suppress Tumor Growth and Enhance Immunotherapy. Cancer Cell 2019, 36, 483-497.e415. [CrossRef]

154. Quach, H.; Ritchie, D.; Stewart, A.K.; Neeson, P.; Harrison, S.; Smyth, M.J.; Prince, H.M. Mechanism of action of immunomodulatory drugs (IMiDS) in multiple myeloma. Leukemia 2010, 24, 22-32. [CrossRef] [PubMed]

155. Gribben, J.G.; Fowler, N.; Morschhauser, F. Mechanisms of Action of Lenalidomide in B-Cell Non-Hodgkin Lymphoma. J. Clin. Oncol. 2015, 33, 2803-2811. [CrossRef] [PubMed]

156. Lopez-Girona, A.; Heintel, D.; Zhang, L.H.; Mendy, D.; Gaidarova, S.; Brady, H.; Bartlett, J.B.; Schafer, P.H.; Schreder, M.; Bolomsky, A.; et al. Lenalidomide downregulates the cell survival factor, interferon regulatory factor-4, providing a potential mechanistic link for predicting response. Br. J. Haematol. 2011, 154, 325-336. [CrossRef] [PubMed]

157. Lu, G.; Middleton, R.E.; Sun, H.; Naniong, M.; Ott, C.J.; Mitsiades, C.S.; Wong, K.K.; Bradner, J.E.; Kaelin, W.G., Jr. The myeloma drug lenalidomide promotes the cereblon-dependent destruction of Ikaros proteins. Science 2014, 343, 305-309. [CrossRef] [PubMed]

158. Chamuleau, M.E.D.; Burggraaff, C.N.; Nijland, M.; Bakunina, K.; Mous, R.; Lugtenburg, P.J.; Dierickx, D.; van Imhoff, G.W.; Vermaat, J.S.P.; Marijt, E.A.F.; et al. Treatment of patients with MYC rearrangement positive large B-cell lymphoma with R-CHOP plus lenalidomide: Results of a multicenter HOVON phase II trial. Haematologica 2019. [CrossRef] [PubMed]

159. Labrijn, A.F.; Janmaat, M.L.; Reichert, J.M.; Parren, P. Bispecific antibodies: A mechanistic review of the pipeline. Nat. Rev. Drug Discov. 2019, 18, 585-608. [CrossRef] [PubMed]

160. Goebeler, M.E.; Knop, S.; Viardot, A.; Kufer, P.; Topp, M.S.; Einsele, H.; Noppeney, R.; Hess, G.; Kallert, S.; Mackensen, A.; et al. Bispecific T-Cell Engager (BiTE) Antibody Construct Blinatumomab for the Treatment of Patients With Relapsed/Refractory Non-Hodgkin Lymphoma: Final Results From a Phase I Study. J. Clin. Oncol. 2016, 34, 1104-1111. [CrossRef]

161. Viardot, A.; Goebeler, M.E.; Hess, G.; Neumann, S.; Pfreundschuh, M.; Adrian, N.; Zettl, F.; Libicher, M.; Sayehli, C.; Stieglmaier, J.; et al. Phase 2 study of the bispecific T-cell engager (BiTE) antibody blinatumomab in relapsed/refractory diffuse large B-cell lymphoma. Blood 2016, 127, 1410-1416. [CrossRef] 
162. Buhmann, R.; Simoes, B.; Stanglmaier, M.; Yang, T.; Faltin, M.; Bund, D.; Lindhofer, H.; Kolb, H.J. Immunotherapy of recurrent B-cell malignancies after allo-SCT with Bi20 (FBTA05), a trifunctional anti-CD3 $\mathrm{x}$ anti-CD20 antibody and donor lymphocyte infusion. Bone Marrow Transplant. 2009, 43, 383-397. [CrossRef] [PubMed]

163. Darvin, P.; Toor, S.M.; Sasidharan Nair, V.; Elkord, E. Immune checkpoint inhibitors: Recent progress and potential biomarkers. Exp. Mol. Med. 2018, 50, 1-11. [CrossRef] [PubMed]

164. Ansell, S.M.; Lesokhin, A.M.; Borrello, I.; Halwani, A.; Scott, E.C.; Gutierrez, M.; Schuster, S.J.; Millenson, M.M.; Cattry, D.; Freeman, G.J.; et al. PD-1 blockade with nivolumab in relapsed or refractory Hodgkin's lymphoma. N. Engl. J. Med. 2015, 372, 311-319. [CrossRef] [PubMed]

165. Younes, A.; Santoro, A.; Shipp, M.; Zinzani, P.L.; Timmerman, J.M.; Ansell, S.; Armand, P.; Fanale, M.; Ratanatharathorn, V.; Kuruvilla, J.; et al. Nivolumab for classical Hodgkin's lymphoma after failure of both autologous stem-cell transplantation and brentuximab vedotin: A multicentre, multicohort, single-arm phase 2 trial. Lancet Oncol. 2016, 17, 1283-1294. [CrossRef]

166. Ansell, S.M.; Minnema, M.C.; Johnson, P.; Timmerman, J.M.; Armand, P.; Shipp, M.A.; Rodig, S.J.; Ligon, A.H.; Roemer, M.G.M.; Reddy, N.; et al. Nivolumab for Relapsed/Refractory Diffuse Large B-Cell Lymphoma in Patients Ineligible for or Having Failed Autologous Transplantation: A Single-Arm, Phase II Study. J. Clin. Oncol. 2019, 37. [CrossRef]

167. Smith, S.D.; Till, B.G.; Shadman, M.S.; Lynch, R.C.; Cowan, A.J.; Wu, Q.W.; Voutsinas, J.; Rasmussen, H.A.; Blue, K.; Ujjani, C.S.; et al. Pembrolizumab with R-CHOP in previously untreated diffuse large B-cell lymphoma: Potential for biomarker driven therapy. Br. J. Haematol. 2020. [CrossRef]

168. Advani, R.; Flinn, I.; Popplewell, L.; Forero, A.; Bartlett, N.L.; Ghosh, N.; Kline, J.; Roschewski, M.; LaCasce, A.; Collins, G.P.; et al. CD47 Blockade by Hu5F9-G4 and Rituximab in Non-Hodgkin's Lymphoma. N. Engl. J. Med. 2018, 379, 1711-1721. [CrossRef]

169. Kawashima, I.; Inamoto, Y.; Maeshima, A.M.; Nomoto, J.; Tajima, K.; Honda, T.; Shichijo, T.; Kawajiri, A.; Takemura, T.; Onishi, A.; et al. Double-Expressor Lymphoma Is Associated with Poor Outcomes after Allogeneic Hematopoietic Cell Transplantation. Biol. Blood Marrow Transplant. 2018, 24, 294-300. [CrossRef]

170. Herrera, A.F.; Rodig, S.J.; Song, J.Y.; Kim, Y.; Griffin, G.K.; Yang, D.; Nikolaenko, L.; Mei, M.; Bedell, V.; Dal Cin, P.; et al. Outcomes after Allogeneic Stem Cell Transplantation in Patients with Double-Hit and Double-Expressor Lymphoma. Biol. Blood Marrow Transplant. 2018, 24, 514-520. [CrossRef]

171. June, C.H.; O'Connor, R.S.; Kawalekar, O.U.; Ghassemi, S.; Milone, M.C. Car T cell immunotherapy for human cancer. Science 2018, 359, 1361-1365. [CrossRef]

172. Singh, K.; Lin, J.; Zhong, Y.; Burcul, A.; Mohan, P.; Jiang, M.; Sun, L.; Yong-Gonzalez, V.; Viale, A.; Cross, J.R.; et al. c-MYC regulates mRNA translation efficiency and start-site selection in lymphoma. J. Exp. Med. 2019, 216, 1509-1524. [CrossRef] [PubMed]

173. Schuster, S.J.; Bishop, M.R.; Tam, C.S.; Waller, E.K.; Borchmann, P.; McGuirk, J.P.; Jager, U.; Jaglowski, S.; Andreadis, C.; Westin, J.R.; et al. Tisagenlecleucel in Adult Relapsed or Refractory Diffuse Large B-Cell Lymphoma. N. Engl. J. Med. 2019, 380, 45-56. [CrossRef]

174. Locke, F.L.; Ghobadi, A.; Jacobson, C.A.; Miklos, D.B.; Lekakis, L.J.; Oluwole, O.O.; Lin, Y.; Braunschweig, I.; Hill, B.T.; Timmerman, J.M.; et al. Long-term safety and activity of axicabtagene ciloleucel in refractory large B-cell lymphoma (ZUMA-1): A single-arm, multicentre, phase 1-2 trial. Lancet Oncol. 2019, 20, 31-42. [CrossRef]

175. Abramson, J.S.; Palomba, M.L.; Gordon, L.I.; Lunning, M.A.; Wang, M.; Arnason, J.; Mehta, A.; Purev, E.; Maloney, D.G.; Andreadis, C.; et al. Lisocabtagene maraleucel for patients with relapsed or refractory large B-cell lymphomas (TRANSCEND NHL 001): A multicentre seamless design study. Lancet 2020. [CrossRef]

176. Fry, T.J.; Shah, N.N.; Orentas, R.J.; Stetler-Stevenson, M.; Yuan, C.M.; Ramakrishna, S.; Wolters, P.; Martin, S.; Delbrook, C.; Yates, B.; et al. CD22-targeted CAR T cells induce remission in B-ALL that is naive or resistant to CD19-targeted CAR immunotherapy. Nat. Med. 2018, 24, 20-28. [CrossRef] [PubMed]

177. Pan, J.; Niu, Q.; Deng, B.; Liu, S.; Wu, T.; Gao, Z.; Liu, Z.; Zhang, Y.; Qu, X.; Zhang, Y.; et al. CD22 CAR T-cell therapy in refractory or relapsed B acute lymphoblastic leukemia. Leukemia 2019, 33, 2854-2866. [CrossRef] [PubMed] 
178. Wang, C.M.; Wu, Z.Q.; Wang, Y.; Guo, Y.L.; Dai, H.R.; Wang, X.H.; Li, X.; Zhang, Y.J.; Zhang, W.Y.; Chen, M.X.; et al. Autologous T Cells Expressing CD30 Chimeric Antigen Receptors for Relapsed or Refractory Hodgkin Lymphoma: An Open-Label Phase I Trial. Clin. Cancer Res. 2017, 23, 1156-1166. [CrossRef]

179. Ramos, C.A.; Ballard, B.; Zhang, H.; Dakhova, O.; Gee, A.P.; Mei, Z.; Bilgi, M.; Wu, M.F.; Liu, H.; Grilley, B.; et al. Clinical and immunological responses after CD30-specific chimeric antigen receptor-redirected lymphocytes. J. Clin. Investig. 2017, 127, 3462-3471. [CrossRef]

180. Ormhøj, M.; Scarfo, I.; Cabral, M.L.; Bailey, S.R.; Lorrey, S.J.; Bouffard, A.A.; Castano, A.P.; Larson, R.C.; Riley, L.S.; Schmidts, A.; et al. Chimeric Antigen Receptor T Cells Targeting CD79b Show Efficacy in Lymphoma with or without Cotargeting CD19. Clin. Cancer Res. 2019, 25, 7046-7057. [CrossRef]

181. Jiang, D.; Tian, X.; Bian, X.; Zhu, T.; Qin, H.; Zhang, R.; Xu, Y.; Pan, Z.; Huang, H.; Fu, J.; et al. T cells redirected against Igbeta for the immunotherapy of B cell lymphoma. Leukemia 2020, 34, 821-830. [CrossRef]

182. Shimizu, K.; Iyoda, T.; Yamasaki, S.; Kadowaki, N.; Tojo, A.; Fujii, S. NK and NKT Cell-Mediated Immune Surveillance against Hematological Malignancies. Cancers 2020, 12, 817. [CrossRef] [PubMed]

183. Casey, S.C.; Baylot, V.; Felsher, D.W. The MYC oncogene is a global regulator of the immune response. Blood 2018, 131, 2007-2015. [CrossRef] [PubMed]

184. Dose, M.; Khan, I.; Guo, Z.; Kovalovsky, D.; Krueger, A.; von Boehmer, H.; Khazaie, K.; Gounari, F. c-Myc mediates pre-TCR-induced proliferation but not developmental progression. Blood 2006, 108, 2669-2677. [CrossRef] [PubMed]

185. Zhang, B.; Jiao, A.; Dai, M.; Wiest, D.L.; Zhuang, Y. Id3 Restricts gammadelta NKT Cell Expansion by Controlling Egr2 and c-Myc Activity. J. Immunol. 2018, 201, 1452-1459. [CrossRef] [PubMed]

186. Wang, R.; Dillon, C.P.; Shi, L.Z.; Milasta, S.; Carter, R.; Finkelstein, D.; McCormick, L.L.; Fitzgerald, P.; Chi, H.; Munger, J.; et al. The transcription factor Myc controls metabolic reprogramming upon Tymphocyte activation. Immunity 2011, 35, 871-882. [CrossRef]

187. Trumpp, A.; Refaeli, Y.; Oskarsson, T.; Gasser, S.; Murphy, M.; Martin, G.R.; Bishop, J.M. c-Myc regulates mammalian body size by controlling cell number but not cell size. Nature 2001, 414, 768-773. [CrossRef]

188. Cichocki, F.; Hanson, R.J.; Lenvik, T.; Pitt, M.; McCullar, V.; Li, H.; Anderson, S.K.; Miller, J.S. The transcription factor c-Myc enhances KIR gene transcription through direct binding to an upstream distal promoter element. Blood 2009, 113, 3245-3253. [CrossRef]

189. Dong, H.; Adams, N.M.; Xu, Y.; Cao, J.; Allan, D.S.J.; Carlyle, J.R.; Chen, X.; Sun, J.C.; Glimcher, L.H. The IRE1 endoplasmic reticulum stress sensor activates natural killer cell immunity in part by regulating c-Myc. Nat. Immunol. 2019, 20, 865-878. [CrossRef]

190. Abramson, J.S.; Siddiqi, T.; Palomba, M.L.; Gordon, L.I.; Lunning, M.A.; Arnason, J.E.; Wang, M.; Forero-Torres, A.; Albertson, T.; Dehner, C.; et al. High Durable CR Rates and Preliminary Safety Profile for JCAR017 in R/R Aggressive B-NHL (TRANSCEND NHL 001 Study): A Defined Composition CD19-Directed CAR T Cell Product with Potential for Outpatient Administration. Biol. Blood Marrow Transplant. 2018, 24, S25. [CrossRef]

Publisher's Note: MDPI stays neutral with regard to jurisdictional claims in published maps and institutional affiliations.

(C) 2020 by the authors. Licensee MDPI, Basel, Switzerland. This article is an open access article distributed under the terms and conditions of the Creative Commons Attribution (CC BY) license (http://creativecommons.org/licenses/by/4.0/). 